\title{
Long Term Displacement Data of Woven Fabric Webbings under Constant Load for Inflatable Structures
}

\author{
Winfred S. Kenner ${ }^{1}$, Thomas C. Jones ${ }^{2}$, and William R. Doggett ${ }^{3}$ \\ NASA Langley Research Center, Hampton, Virginia, 23681-2199 \\ Melvin H. Lucy ${ }^{4}$, Trevor A. Grondin ${ }^{5}$, Karen S. Whitley ${ }^{6}$, Quinton Duncan ${ }^{7}$, and James V. Plant ${ }^{8}$ \\ NASA Langley Research Center, Hampton, Virginia, 23681-2199
}

\begin{abstract}
Inflatable modules for space applications offer weight and launch volume savings relative to current metallic modules. Limited data exist on the creep behavior of the restraint layer of inflatable modules. Long-term displacement and strain data of two high strength woven fabric webbings, Kevlar and Vectran, under constant load is presented. The creep behavior of webbings is required by designers to help determine service life parameters of inflatable modules. Four groups of different webbings with different loads were defined for this study. Group 1 consisted of $4 \mathrm{~K}$ Kevlar webbings loaded to $33 \%$ ultimate tensile strength and $6 \mathrm{~K}$ Vectran webbings loaded to $27 \%$ ultimate tensile strength, group 2 consisted of $6 \mathrm{~K}$ Kevlar webbings loaded to $40 \%$ and $43 \%$ ultimate tensile strength, and $6 \mathrm{~K}$ Vectran webbings loaded to $50 \%$ ultimate tensile strength, group 3 consisted of $6 \mathrm{~K}$ Kevlar webbings loaded to $52 \%$ ultimate tensile strength and $6 \mathrm{~K}$ Vectran webbings loaded to $60 \%$ ultimate tensile strength, and group 4 consisted of $12.5 \mathrm{~K}$ Kevlar webbings loaded to $22 \%$ ultimate tensile strength, and 12.5K Vectran webbings loaded to $22 \%$ ultimate tensile strength. The uniquely designed test facility, hardware, displacement measuring devices, and test data are presented. Test data indicate that immediately after loading all webbings stretch an inch or more, however as time increases displacement values significantly decrease to fall within a range of several hundredth of an inch over the remainder of test period. Webbings in group 1 exhibit near constant displacements and strains over a 17-month period. Data acquisition was suspended after the $17^{\text {th }}$ month, however webbings continue to sustain load without any local webbing damage as of the $21^{\text {st }}$ month of testing. Webbings in group 2 exhibit a combination of initial constant displacement and subsequent increases in displacement rates over a 16-month period. Webbings in group 3 exhibit steady increases in displacement rates leading to webbing failure over a 3-month period. Five of six webbings experienced local damage and subsequent failure in group 3. Data from group 4 indicates increasing webbing displacements over a 7-month period. All webbings in groups 1, 2, and 4 remain suspended without any local damage as of the writing of this paper. Variations in facility temperatures over test period seem to have had limited effect on long-term webbing displacement data.
\end{abstract}

\footnotetext{
${ }^{1}$ Aerospace Engineer, Structural Mechanics and Concepts Branch, Mail Stop 190

${ }^{2}$ Aerospace Engineer, Structural Mechanics and Concepts Branch, Mail Stop 190

${ }^{3}$ Aerospace Engineer, Structural Mechanics and Concepts Branch, Mail Stop 190

${ }^{4}$ Senior Aerospace Engineer, Electronic Systems Branch, Mail Stop 488

${ }^{5}$ Aerospace Engineer, Mechanical Systems Branch, Mail Stop 466

${ }^{6}$ Senior Aerospace Engineer, retired

${ }^{7}$ Lead Engineering Technician, Structures Experiments Branch, Mail Stop 188F

${ }^{8}$ Engineering Technician, Materials Experiment Branch, Mail Stop 419
} 


\section{Nomenclature}

$\begin{array}{ll}r & =\text { radius } \\ P & =\text { pressure } \\ \mathrm{t} & =\text { thickness } \\ \text { in } & =\text { inch } \\ \sigma_{\mathrm{h}} & =\text { hoop stress } \\ \sigma_{1} & =\text { longitudinal stress } \\ \text { FS } & =\text { Factor of Safety }\end{array}$

\section{Introduction}

$\mathrm{I}_{\mathrm{e}}^{\mathrm{n}}$ flatable space structures have been utilized in various aerospace applications [1-5] for over 30 years. Three xamples of inflatable aerospace structures are shown in Figure 1. Inflatable space modules, a subset of inflatable structures, are currently being developed by NASA and private companies for potential weight and launch storage savings relative to metallic space modules. Current metallic space modules are limited in size to the diameter of the launch vehicle. An inflatable space module can uniquely be stored in a small package, and deployed on orbit to provide an increased working volume for astronauts (Fig. 2). They can also be designed for lunar or Mars surface applications at lower costs than metallic structures. An illustration of an inflatable module technology demonstrator for surface application is presented in Figure. 3. Inflatable modules are typically designed with cylindrical or spherical configurations to simplify material and structural analyses (Fig. 4.). Along with desirable characteristics, inflatable modules have risk factors. The walls of inflatable space modules are typically constructed of an: 1) attenuation barrier consisting of radiation, thermal, and micrometeroid and orbital debris (MMOD) layers, 2) internal gas retention layer consisting of a flexible bladder, and 3) load-bearing restraint layer which typically consist of high strength woven materials or webbings. Once an inflatable module is deployed with a defined internal pressure the wall or shell loads are primarily carried by the restraint layer. Over extended periods of time these loads can potentially cause the restraint layer to creep, degrade, and fail. Definition of stresses and strains within a restraint layer, and definition of viable restraint layer materials that can sustain loads over extended periods of time are necessary for designers to validate material performance and predict service life of inflatable modules. Proposed inflatable space modules are envisioned to have a service life that is comparable to the service life of metallic space modules. The study and characterization of the creep behavior of restraint layer materials offers a means to mitigate the risk of degradation or failure over the service life of an inflatable module.

The database of material and mechanical properties for woven materials for aerospace application is substantially smaller than the comparable database of mechanical properties for metallic or composite materials. In general, aerospace designers and engineers rely on well-defined material properties in the conceptual and developmental phases of new aerospace structures. Designers also apply a factor of safety to final designs to lower the risk of structural degradation under complex loading. Metals are ideal materials for aerospace structures because they have well defined material properties across a wide range of thermo-mechanical loads. The use of A-basis or B-basis material allowable strength values within a structural design is one of the best means to lower risk and insure structural viability. A-basis allowable strength values are available for most aluminum alloys and in general B-basis allowable strength values are available for common autoclave polymer matrix composite materials (Fig. 5). Woven materials consist of flexible natural or synthetic interwoven fibers, and are defined as viscoelastic. Viscoelastic materials exhibit nonlinear behavior under load and over time [6]. Mechanical properties of woven materials are typically generated per roll of material through experimental test. Webbings are customized long narrow straps of woven material. The restraint layer of an inflatable structure can consist of hundreds or thousands of webbings.

The current study on webbings evolved from previous lightweight material projects and programs conducted at NASA Langley Research Center (LaRC) and Johnson Space Center (JSC). NASA initiated the Structures, Materials, and Mechanisms, (SMM) project under the Exploration Technology Development Program (ETDP) at LaRC in 2007 to develop viable lightweight materials for space exploration. One technical task under SMM was the development of technologies for advancement of lightweight inflatable habitat structures. The ultimate tensile strength of both pristine and damaged webbings, as well as thermal effects were studied. Another technical task under, SMM, researched lightweight parachute materials for the Orion space capsule, with the development of high strength fibers and yarns as a focus. The SMM project also leveraged previous inflatable habitat work from JSC's TransHab, a prominent NASA inflatable module habitat technology development program from 1988 to 1998 . The TransHab program was initiated to investigate the possible replacement of metallic habitats with inflatable habitats on the International Space Station. Work included inflatable module deployment procedures, internal hardware layout, and a review of viable materials for the multilayered inflatable shell like wall. Kevlar was selected as the 
baseline restraint layer material for Transhab, and a database of mechanical properties was generated via experimental test.

The current study was conducted under the, Lightweight, Materials, and Structures (LMS) project under the Game Changing Development Program at LaRC, which evolved from the SMM project under the ETDP program. In addition, a parallel study on a novel accelerated creep methodology was conducted under the LMS project. Results will be published in a separate paper [7]. A limited number of long term material creep studies have been conducted on webbings due to the complexity of large scale hardware requirements and desired thermal and humidity environmental conditions. The current study will leverage previous work from both Transhab and SMM programs.

\section{Approach}

\section{A. Objective}

The objective of this study is to characterize the long-term progressive deformation of high strength Kevlar and Vectran webbings over a range of low to medium applied loads. In a generic sense, this is a long-term creep study on woven materials. A limitation of the study, due to experimental constraints is that temperature and humidity are not held constant, yet meaningful conclusions may still be drawn. Two high strength webbings configurations were selected for study, one of Kevlar and one of Vectran. The particular configuration of Kevlar studied was selected to leverage previous work conducted under the Transhab program. The Vectran webbing studied was selected due to the manufacturer's claim of significant improved creep life performance over high-strength aramid fibers such as Kevlar. Test hardware, test procedures, and test data for experimental tests will be presented.

\section{B. Creep Theory}

Creep is the progressive deformation of a material at constant stress and constant temperature. Creep behavior has three classic stages, primary, secondary, and tertiary (Fig. 6). Primary creep is a transient stage during which the material deforms at a decreasing strain rate. Deformation is primarily elastic, but the total creep strain is only partially recoverable, therefore some plastic deformation is also present. Deformation occurs at a molecular level in aligning the polymer backbones within the crystal structure, through slip and chain-direction shear. Webbing materials exhibit decrimping and fiber locking during the primary stage with the amount of recovery at both levels dependent on applied load. The primary creep stage may be short due to the highly oriented polymeric structure initially present in webbings, and because a majority of chain alignments are accomplished during processing.

Webbing materials may exhibit near constant creep strain or positively-sloped creep strain rates over an extended time period during the secondary stage. Positively-sloped creep strain rates equate to a gradual reduction in the strain rate in linear time, which suggests a strain hardening of the material throughout its time to failure. Materials exhibit necking during the tertiary phase, which reduces the cross-sectional area of the specimen, leading to higher local stresses and a rapidly increasing strain rate until failure. The Poisson necking effect is very small for high strength webbing due to a very low percentage of fill yarns, therefore a typical tertiary stage is not prominent.

\section{Specimen Description}

High strength Kevlar and Vectran webbing materials were selected for testing in this study. In general a segment of webbing consist of vertical warp yarns with horizontal fill yarns woven together in a defined $0^{\circ}$ and $90^{\circ}$ angle pattern. A typical roll and a flat segment of Vectran webbing are shown in Figure 7. Kevlar and Vectran webbings are manufactured in runs of several thousand yards from which rolls of 25 to 60 yards of material are cut. The test material webbings for this study consisted of: 1.) Kevlar nominally rated for 4,000 lbs/inch, 2.) Kevlar nominally rated for 6,000 lbs/inch, 3.) Kevlar nominally rated for $12,500 \mathrm{lbs} / \mathrm{inch}$, 4.) Vectran nominally rated for 6,000 lbs/inch and 5.) Vectran nominally rated for $12,500 \mathrm{lbs} / \mathrm{inch}$, henceforth referred to as "4K Kevlar", "6K Kevlar”, "12.5K Kevlar", "6K Vectran”, and "12.5K Vectran”, respectively. All webbings are 1-inch wide, and material specifications for $6 \mathrm{~K}$ and $12.5 \mathrm{~K}$ webbings are presented in Table 1. The Mil-T-87130 manufacturing specifications for the $6 \mathrm{~K}$ and $12.5 \mathrm{~K}$ webbings are presented in Table 2. Specifications for the $4 \mathrm{~K}$ Kevlar webbing were not available. Note, all webbings had a former USAF military specification for para-aramid webbings and tapes and now have been reissued with a Parachute Industry Association specification, PIA-T-87130B. Kevlar is an aromatic polyamide, or aramid, which is a lyotropic liquid crystal polymer (LCP), where the liquid crystalline phase exists upon dissolution of the polymer in a solvent. The lyotropic LPC is then spun into fibers, with the liquid crystalline order resulting in a highly oriented fiber structure. Mil-T-87130 was created for para-aramids, which are long chain aramids that include Kevlar, Technora and Twaron. Vectran is not an aramid, but rather an aromatic polyester an 
arester [sic] which is a thermotropic LCP, where the liquid crystalline phase is exhibited over a particular temperature range. Vectran fibers are created through melt-spinning involving extrusion through a die.

Kevlar and Vectran webbing manufacturers provide a strength rating per roll of material. The provided strength value is typically conservative and only applicable for short periods of utilization. Determination of an accurate strength value per roll will provide guidance on the applied load for long duration testing. Five webbings from a roll were tested to failure, and the failure loads were averaged to obtain an average UTS value per roll. The UTS testing follows the ASTM-D-6775-02 standard test method for breaking strength and elongation of textile webbing, tape and braided material.

Table 1. Material specifications for $6 \mathrm{~K}$ and $12.5 \mathrm{~K}$ Kevlar and Vectran webbings.

\begin{tabular}{|c|c|c|c|c|c|}
\hline Webbing & 4K Kevlar & 6K Kevlar & $6 \mathrm{~K}$ Vectran & 12.5K Kevlar & 12.5K Vectran \\
\hline Type & - & $\begin{array}{l}1991-1 \text { “" } \\
\text { Natural "R" } \\
\text { Kevlar tape }\end{array}$ & $\begin{array}{lr}6996-1 " & \text { Natural } \\
\text { "R" } & \text { Vectran } \\
6,000 \text { lb webbing }\end{array}$ & $\begin{array}{lr}2736-1 " \quad \text { Natural } \\
\text { Kevlar } & \text { "R" } \\
\text { Treated } & \text { webbing }\end{array}$ & $\begin{array}{l}\text { 1" Natural Vectran } \\
\text { webbing }(100 \% \text { Vectran })\end{array}$ \\
\hline Spec & - & $\begin{array}{l}\text { Mil-T-87130 Type } \\
\text { VI Class } 9 \text { Mod to R }\end{array}$ & $\begin{array}{l}\text { Mil-T-87130 } \\
\text { Type VI Class } 9 \\
\text { Mod to R }\end{array}$ & $\begin{array}{l}\text { Mil-T-87130 } \\
\text { Type VI Class } 11 \\
\text { Mod }\end{array}$ & $\begin{array}{l}\text { Mil-T-87130 Type } \text { VI } \\
\text { Class } 11 \text { Mod to R }\end{array}$ \\
\hline Put-up & - & $\begin{array}{l}60 \text { Yard Rolls, } 15 \\
\text { Yard Mutts }(+1 /-0)\end{array}$ & $\begin{array}{l}25 \text { yard rolls } \\
(-0 /+1)\end{array}$ & $\begin{array}{l}25 \text { yard rolls } \\
(+1 /-0)\end{array}$ & 50 yard rolls \\
\hline Vendor & - & Bally Ribbon & Bally Ribbon & Bally Ribbon & $\begin{array}{l}\text { Offray Specialty Narrow } \\
\text { Fabrics }\end{array}$ \\
\hline Finish & & (D) & 510 & & \\
\hline
\end{tabular}

Table 2. Mil-T-87130 manufacturing specifications for $6 \mathrm{~K}$ and $12.5 \mathrm{~K}$ webbings.

\begin{tabular}{|c|c|c|c|c|c|c|c|c|c|c|c|c|}
\hline \multicolumn{4}{|c|}{ Mil-T-87130 Specification } & \multicolumn{3}{|c|}{ Lineal Density } & \multicolumn{6}{|c|}{ WARP (Axial Threads) Properties } \\
\hline $\begin{array}{l}\text { Minimum } \\
\text { UTS } \\
\text { (lbs) }\end{array}$ & $\begin{array}{l}\text { Width } \\
\text { (inches) }\end{array}$ & Type & Class & $\begin{array}{l}\text { Max } \\
\mathrm{Wt} \\
\text { (oz/yd) }\end{array}$ & $\begin{array}{l}\text { Max } \\
\text { M/L } \\
\text { (lbs/in) }\end{array}$ & $\begin{array}{c}\text { Total } \\
\mathrm{M} / \mathrm{L}\end{array}$ & Denier & Ply & $\begin{array}{l}\text { Total } \\
\text { Ends } \\
\text { Minimum }\end{array}$ & $\begin{array}{c}\text { Fiber } \\
\text { M/L } \\
(\mathrm{lbs} / \mathrm{in})\end{array}$ & $\begin{array}{l}\text { Warp } \\
\text { (lbs/in) }\end{array}$ & $\begin{array}{l}\% \text { Warp } \\
\text { by mass }\end{array}$ \\
\hline 6000 & 1 & VI & 9 & 1 & 0.001736 & 0.00132 & 1500 & 3 & 44 & $9.333 \mathrm{E}-\mathrm{C}$ & 0.0 & 0.9296 \\
\hline 12500 & 1 & VI & 11 & 1.65 & 0.002865 & 0.002576 & 1500 & 3 & 89 & $9.333 \mathrm{E}-06$ & 0.002492 & 0.9674 \\
\hline
\end{tabular}

\begin{tabular}{|c|c|c|c|c|c|c|c|c|c|c|}
\hline \multicolumn{4}{|c|}{ Mil-T-87130 Specification } & & \multicolumn{6}{|c|}{ FILL or WEFT (Cross Threads) Properties } \\
\hline $\begin{array}{l}\text { Minimum } \\
\text { UTS } \\
\text { (lbs) }\end{array}$ & $\begin{array}{l}\text { Width } \\
\text { (inches) }\end{array}$ & Type & Class & $\begin{array}{l}\text { Weave } \\
\text { Type }\end{array}$ & Denier & Ply & $\begin{array}{c}\text { Picks } \\
\text { (per } \\
\text { inch) }\end{array}$ & $\begin{array}{l}\text { Fiber } \\
\mathrm{M} / \mathrm{L} \\
\text { (lbs/in) }\end{array}$ & $\begin{array}{c}\text { Weft M/L } \\
\text { (lbs/in) }\end{array}$ & $\begin{array}{c}\% \text { Fill } \\
\text { by mass }\end{array}$ \\
\hline 6000 & 1 & VI & 9 & Plain & 1500 & 1 & 10 & $9.333 \mathrm{E}-06$ & $9.333 \mathrm{E}-05$ & 0.0704 \\
\hline 12500 & 1 & VI & 11 & Plain & 1500 & 1 & 9 & $9.333 \mathrm{E}-06$ & $8.3996 \mathrm{E}-05$ & 0.0326 \\
\hline
\end{tabular}

\section{Experimental Setup}

All tests were conducted in an enclosed 20 -foot by 30 -foot facility at NASA LaRC. Three large-scale I-beam structures were designed and assembled to enable testing of numerous webbing materials within the defined space (Figures 8-11). Experimental test hardware consisted of: three rows of steel I-beam structures, concrete weights, landing platforms for concrete weights, upper and lower webbing restraint fixtures, and displacement transducers and targets. Three rows were defined within the facility for three I-beam structures. All were double-cantilevered Ibeam structures with the first row 12-feet tall, the second row 20-feet tall, and the third row 14-feet tall. The height per I-beam structure is proportional to the height of the associated concrete weight. Two types of concrete weights were utilized to load the webbings: 1.) 1800-lbs concrete block, and 2.) 2800-lbs concrete culvert. The 1800-lbs concrete weight has a 2 -foot by 2 -foot by 3 -foot block geometry, and the 2800-lbs concrete culvert has an 8 -foot long by 32 -inch diameter cylindrical geometry.

Two webbing restraint fixtures were designed for this study, basic and custom (Fig. 12). The basic restraint fixture consists of a standard shackle and pin. The design is cost effective, easy to assemble, and easy to install. The custom restraint fixture was designed to support three anchors and three cables for three linear displacement transducers. The webbing installation procedure per restraint fixture, consist of uniquely wrapping the loose end of the webbing sample around the two pins of the upper restraint fixture, as illustrated in Figures 9d for the basic fixture and $9 \mathrm{f}$ for the custom fixture. The same procedure is repeated on the lower restraint fixture. Both restraint 
fixtures are only stable after the application of the tension load by hanging the applied weight. The upper restraint fixture is attached to an I-beam clamp; which is attached to the lower flange of the cantilevered I-beam, and the lower restraint fixture is attached to the concrete weight.

The photogrammetry method and linear displacement transducers were selected to measure webbing displacements. Photogrammetry utilizes small unique targets and a photogrammetry camera, which can accurately capture the location of dispersed targets relative to one another in space. Prior to test start, targets were applied to all hardware items, upper and lower restraint fixtures, I-beam structure, and webbing material (Fig. 9a-c). Next, the location of all targets are captured by the photogrammetry camera. The upper and lower targets on the webbing are isolated and the distance between the two is identified as the initial length of the webbing material. Load is applied to the webbing and another photogrammetry recording is taken. The new distance between upper and lower targets on the webbing is calculated. The difference between the initial recording and subsequent recordings is defined as the measure of webbing deformation (Fig. 13). A V-Stars ${ }^{\mathrm{TM}}$ photogrammetry camera system was utilized in this study, and it is the most accurate system of its type in the industry and routinely exceeds normal accuracies when used in controlled conditions. Normal accuracies are stated in terms of the field of view of the object being measured. For example, if the object (or field of view) being measured was 5 meters, then a typical accuracy would be $1 \mathrm{~mm}$ for the object using the 1:5000 assumption. The V-Stars system is self-calibrating and its calibration and measurements are tied to the "scale" standards included in the imagery during the measurement process. These scale standards are typically manufactured from materials (INVAR) with a low TCE and have NIST traceable calibrations. The typical accuracy of the scale standards used in measurements at NASA LaRC is 0.0005 inches. Photogrammetry is a reliable noncontact means of obtaining minute changes in webbing length, however measurements could only be taken once a day due to time constraints. Linear displacement transducers were utilized as an alternative means of capturing continuous displacement data over time. Prior to test start an anchor and cable hardware appenditures are attached to the upper custom restraint fixture. Next, transducers are attached to the lower custom restraint fixture. Transducer heads are both extendable and retractable. The head of the transducer is attached to the cable. Slack in the cable during setup is desired so that the head of the transducer isn't pulled out or otherwise damaged. Once the webbing and hardware are aligned, slack in the transducer cable is removed. Note, however that a level of slack does exist in the transducer cable, which makes obtaining an initial webbing length difficult at test start. The weight is suspended and the webbing experiences displacement which coincides with the extension of the transducer head. The transducer extension is a measure of webbing extension, and these values are defined as webbing displacement data (Fig. 14). Output voltage data from each transducer was recorded on a stand-alone real time data logger. Data was recorded at a rate of once a second during initial day of webbing suspension, and reduced to once an hour after the fourth or fifth day of webbing suspension. Several types of transducers were utilized in this study. The minimum full scale stroke range, of all transducers, was three inches and the maximum range was six inches. All utilized transducers had an accuracy of at least $1 \%$ full scale. Interior facility temperatures were recorded at a rate of once an hour on a hand held temperature data logger.

Four test groups were defined for this study. The first group consist of five $4 \mathrm{~K}$ Kevlar webbings and five $6 \mathrm{~K}$ Vectran webbings, where each webbing will have an approximate applied load of $1500 \mathrm{lbs} .1500 \mathrm{lb}$ weights were achieved by using a diamond saw to remove $300 \mathrm{lb}$ sections from ten of the $1800 \mathrm{lb}$ weights. The second group consists of four $6 \mathrm{~K}$ Kevlar webbings and three $6 \mathrm{~K}$ Vectran webbings. Two of the $6 \mathrm{~K}$ Kevlar webbings will have an applied load of $2800 \mathrm{lbs}$, and two will have an applied load of $3000 \mathrm{lbs}$. All three $6 \mathrm{~K}$ Vectran webbings will have an applied load of $3000 \mathrm{lbs} .3000 \mathrm{lb}$ culverts were achieved by adding $200 \mathrm{lb}$ sand bags to standard culverts. The third group consists of four $6 \mathrm{~K}$ Kevlar webbings and four Vectran webbings, where each webbings will have an approximate applied load of $3600 \mathrm{lbs} .3600 \mathrm{lb}$ loads were achieved by stacking one concrete block on top of another. Sand bags were added to achieve higher loads. The fourth group consists of two $12.5 \mathrm{~K}$ Kevlar webbings and two $12.5 \mathrm{~K}$ Vectran webbings, where each webbing will have an applied load of approximately $3600 \mathrm{lbs}$. Webbing displacements for group 1 were measured with photogrammetry equipment, due to the relative floor level location of suspended webbings and associated photogrammetry targets. Webbing displacements for groups 2, 3, and 4 were measured with linear displacement transducers. Webbing samples on the second and third rows are located at relatively high locations. Due to the height of the suspended webbings, it was foreseen that obtaining photogrammetry measurements would be difficult. In addition, continuous webbing displacement data was desired, therefore webbing displacements for groups 2,3 , and 4 were measured with linear transducers. 


\section{Experimental Results}

\section{A. Ultimate Tensile Strength Testing and Variance}

UTS values from 87 rolls of material have been obtained from five types of webbing. The average, minimum and maximum UTS for each roll are plotted in Figures 15 and 16, along with the rated load (the minimum load required to meet the Mil-T-87130 specification). The specific percentage variance about the mean is then plotted for all rolls in Figure 17. Figures indicate that Vectran has higher variance than Kevlar in both $6 \mathrm{~K}$ and $12.5 \mathrm{~K}$ architectures, and markedly so in the $12.5 \mathrm{~K}$ webbings, where Vectran exhibits an average variance of $9.4 \%$ versus only $3.7 \%$ for Kevlar. Two of the $12.5 \mathrm{~K}$ Vectran samples displayed variances just below and right at $20 \%$. Variances per sample has a significant effect on the creep test results, as creep life increases exponentially with a linear decrease in percentage of UTS load. As creep tests are performed at a percentage of the average, a $20 \%$ variance in the measured UTS over the sample set may result in as much as an order of magnitude difference in the creep life obtained for that sample set, as some of the specimens will be significantly stronger or weaker than the average.

Figures also indicate a difference in the fidelity with which the two materials meet the specified minimum breaking loads of 6,000 lbs and 12,500 lbs. Only 9 of 21,6K Vectran rolls met the specification when manufactured using the same architecture as the $6 \mathrm{~K}$ Kevlar. JSC requested that additional fibers be added to the original architecture on later manufacturing runs to meet the minimum specification. The $12.5 \mathrm{~K}$ webbings show the opposite trend, with breaking loads up to $48 \%$ higher than the minimum $(18,439 \mathrm{lb})$ in the case of $12.5 \mathrm{~K}$ Vectran, with an average UTS for both $12.5 \mathrm{~K}$ Kevlar and Vectran, approximately $23 \%$ higher than required. Evidently these architectures are not well optimized even for the para-aramids for which they are intended, but Vectran shows a particularly wide variance not just within a roll, but also across a manufacturing run. One $12.5 \mathrm{~K}$ Vectran roll was significantly different from the rest, with an average UTS of $11,548 \mathrm{lbs}$; the only $12.5 \mathrm{~K}$ roll to test below the minimum. Even if that roll is ignored as an aberration, $12.5 \mathrm{~K}$ Vectran still exhibits a range of average UTS values more than twice as wide as $12.5 \mathrm{~K}$ Kevlar. Data indicates a large variance in webbing UTS material properties. As mentioned in the introduction large variances per roll are a common characteristic of woven materials. Test matrix is presented in Table 3, and hardware details per test group are presented in Table 4. Applied weight divided by webbing roll UTS value equals the applied load \% of UTS per webbing. Webbings for tests under groups 2 and 3 came from the same 6K Kevlar roll.

Table 3. Creep test matrix for test groups 1-4.

\begin{tabular}{|l|l|l|l|l|}
\hline Group \# & $\begin{array}{l}\text { Webbing } \\
\text { Materials }\end{array}$ & $\begin{array}{l}\text { Load rating per webbing } \\
\text { roll }(\mathrm{lbs})\end{array}$ & $\begin{array}{l}\text { UTS per webbing roll } \\
(\mathrm{lbs})\end{array}$ & $\begin{array}{l}\text { Tests per webbing } \\
\text { roll }\end{array}$ \\
\hline \multirow{3}{*}{1} & Kevlar & 4000. & 4577. & 5 \\
\cline { 2 - 5 } & Vectran & 6000. & 5573. & 5 \\
\hline \multirow{2}{*}{2} & Kevlar & 6000. & 7038. & 4 \\
\cline { 2 - 5 } & Vectran & 6000. & 6123. & 3 \\
\hline \multirow{2}{*}{3} & Kevlar & 6000. & 7038. & 4 \\
\cline { 2 - 5 } & Vectran & 6000. & 5867. & 4 \\
\hline \multirow{2}{*}{4} & Kevlar & 12500. & 15956. & 2 \\
\cline { 2 - 5 } & Vectran & 12500. & 15933. & 2 \\
\hline
\end{tabular}


Table 4. Applied loads per test groups 1-4.

\begin{tabular}{|l|l|l|l|l|l|l|l|l|l|}
\hline \multirow{2}{*}{$\begin{array}{l}\text { Webbing } \\
\text { material }\end{array}$} & $\begin{array}{l}\text { Test } \\
\#\end{array}$ & \multicolumn{2}{|c|}{ Group 1 } & \multicolumn{2}{c|}{ Group 2 } & \multicolumn{2}{c|}{ Group 3 } & \multicolumn{2}{c|}{ Group 4 } \\
\cline { 2 - 10 } & & $\begin{array}{l}\text { Applied } \\
\text { Load (lbs) }\end{array}$ & $\begin{array}{l}\text { UTS } \\
\%\end{array}$ & $\begin{array}{l}\text { Applied } \\
\text { load (lbs) }\end{array}$ & $\begin{array}{l}\text { UTS } \\
\%\end{array}$ & $\begin{array}{l}\text { Applied } \\
\text { load (lbs) }\end{array}$ & $\begin{array}{l}\text { UTS } \\
\%\end{array}$ & $\begin{array}{l}\text { Applied } \\
\text { load (lbs) }\end{array}$ & $\begin{array}{c}\text { UTS } \\
\%\end{array}$ \\
\hline \multirow{5}{*}{ Kevlar } & 1 & 1450. & 32. & 2800. & 40. & 3687. & 52. & 3506. & 22. \\
\cline { 2 - 10 } & 2 & 1430. & 31. & 2800. & 40. & 3678. & 52. & 3486. & 22. \\
\cline { 2 - 10 } & 3 & 1450. & 32. & 3000. & 42.6 & 3662. & 52. & - & - \\
\cline { 2 - 10 } & 4 & 1460. & 32. & 3000. & 42.6 & 3368. & 48. & - & - \\
\cline { 2 - 10 } & 5 & 1500. & 33. & - & - & - & - & - & - \\
\hline \multirow{5}{*}{ Vectran } & 1 & 1500. & 27. & 3000. & 49. & 3548. & 61. & 3590. & 23. \\
\cline { 2 - 10 } & 2 & 1445. & 26. & 3000. & 49. & 3528. & 60. & 3613. & 23. \\
\cline { 2 - 10 } & 3 & 1450. & 26. & 3000. & 49. & 3560. & 61. & - & - \\
\cline { 2 - 10 } & 4 & 1500. & 27. & - & - & 3228. & 55. & - & - \\
\cline { 2 - 9 } & 5 & 1440. & 26. & - & - & - & - & - & - \\
\hline
\end{tabular}

\section{B. Creep Test Results}

Plots of displacement versus time and strain versus time plots, per webbing group, are presented to provide insight into the creep behavior and material degradation of Kevlar and Vectran webbings under load over extended periods of time. Presented displacement curves with near constant displacement and strain rates indicate the potential for long life, while displacement curves with increasing displacement and strain rates indicate a level of webbing degradation and potential failure. Photogrammetry was utilized to measure displacements in Group 1, and strain values were generated. Linear displacement transducers were utilized to measure displacements in groups 2, 3, and 4. Kevlar and Vectran results are compared to highlight unique webbing behaviors. Experimental testing of webbings in group 1 started in February 2012, with all other groups subsequent. Graphs from group 1 were generated from one discrete displacement data point per 3 to 4 week recording period. Graphs from groups 2, 3, and 4 were generated by selecting data recorded at 12 -hour intervals, $4 \mathrm{am}$ and $4 \mathrm{pm}$ per day, from a master data file. Displacement curves which have straight lines indicate a extended period in which data was not collected. Details and distinguishing features of displacement curves in groups 2 to 4 are emphasized per graph by limiting the maximum absolute range of the y-axis to 0.6 inches. Select graphs have smaller ranges. All webbing displacement and strain graphs were normalized and graphed together for comparison per group.

Group 1 contains long-term data from $4 \mathrm{~K}$ Kevlar and $6 \mathrm{~K}$ Vectran webbings. Creep displacement curves for five 4K Kevlar webbings loaded to $32 \%$ UTS are presented in Figure 18. All curves exhibit large initial displacements, as expected, and all curves exhibit near constant displacements for the subsequent 550-day period. Test \#5 was suspended around day 170 due to unanticipated hardware failure. Creep strain curves for three of the five webbings are presented in Figure 19. Strain curves indicate a 3\% or more stretch per webbing due to load. Two of the five tests were compromised due to unavoidable adverse lighting conditions in the test facility interfering with data collection via photogrammetry. Creep displacement curves for five $6 \mathrm{~K}$ Vectran webbings loaded to $26 \%$ UTS are presented in Figure 20. All data exhibit large initial displacements, as expected, and all data exhibit near constant displacements over the recorded 550-day period. Creep strain curves for three of the five webbings are presented in Figure 21. Strain curves indicate an approximate $4 \%$ stretch per webbing. Again, two of the five tests were compromised due to unavoidable adverse lighting conditions in the test facility interfering with data collection via photogrammetry. Photogrammetry data acquisition for all webbings in group 1 were suspended in late July 2013. As of December 2, 2013, all nine webbings within group 1 are still suspended and show no visible indication of local damage.

Group 2 contains long-term data from $6 \mathrm{~K}$ Kevlar and 6K Vectran webbings. One creep displacement curve for a 6K Kevlar webbings loaded to $40 \%$ UTS, and internal temperature data from the test facility are presented in Figure 22. The displacement curve has better definition than curves generated from photogrammetry data due to the use of a linear displacement transducer to collect continuous displacement data. In addition, the displacement curve exhibits a sinusoid wave pattern. The exact cause of the sinusoidal pattern is unknown, however it was also noticed in the parallel study on accelerated creep [7]. Several factors such as the day by day temperature cycle, noise from the linear displacment transducer, and or incidental vibrations from facility operations could contribute to the sinusoidal response. The displacement curve exhibites a prolonged 100-day plus primary stage; followed by near constant displacement for approximately 300 days. An increase in displacement is noticeable after day 430. No signs 
of local webbing damage are visible. Presented internal ambient facility temperatures indicate a hot and cold cyclic pattern. Ambient temperature variations seem to have had limited to no effect on displacement values from day 200 to day 400. Creep displacement curves for two 6K rated Kevlar webbings loaded to $43 \%$ UTS are presented in Figure 23. Displacement curves exhibit near constant increases over the entire 300-day test period. Local damage is unnoticeable in both webbings. Note a near constant displacement stage seems absent. There is a two hundred $\mathrm{lb}$ load difference between the 40\% UTS case and the 43\% UTS case. Creep displacement curves for three 6K Vectran webbings loaded to 49\% UTS are presented in Figure 24. Tests \#1 and \#2 exhibit near constant displacements for 100-days after primary stage. Intermittent contact between one side of the concrete culvert weight and the associated landing platform caused the initial displacement response in test \#3. The webbing curve exhibited similar behavior to curves \#1 and \#2 after contact was abated. Around day 100, all three curves exhibit noticeable increases in displacement over recorded 200-day period. Local damage is not observed in any webbing.

Group 3 yielded short-term data for $6 \mathrm{~K}$ Kevlar and 6K Vectran webbings. Creep displacement curves for three Kevlar webbings loaded to 52\% UTS are presented in Figure 25. Uniquely, all curves exhibit a prolonged 17-day plus primary stage, a relative short near constant displacement secondary stage, and abrupt webbing failure tertiary stage after a maximum 80-day life for webbing \#1. As previously mentioned, the straight horizontal line in the curve after day 17 indicates a period in which no data was collected. Creep displacement curve for one 6K Kevlar webbing loaded to 48\% UTS over a 100 day period is presented in Figure 26. Displacement curve is similar to curves presented for two 6K Kevlar webbings load to 43\% UTS in Figure 23. The 100-day test period, with no signs of local webbing damage, associated with the $6 \mathrm{~K}$ Kevlar webbing loaded to $48 \%$ UTS is noticeably longer than the 80 day test period of the three failed $6 \mathrm{~K}$ Kevlar webbings loaded to 52\% UTS. Creep displacement curves for three Vectran webbings loaded to $61 \%$ UTS are presented in Figure 27. Curves for webbing \#1 and \#3 are steeper than the curve for webbing \#2. Webbings \#1 and \#3 failed after a 70-day period. The test associated with webbing \#2 was halted after 90-days. Creep curve for one 6K Vectran webbing loaded to 55\% UTS over a 100 day period is presented in Figure 28. Displacement curve is similar to the three displacement curves for $6 \mathrm{~K}$ Vectran webbings loaded to 49\% UTS presented in Figure 24. The 100-day test perod, with no signs of local damage, associated with the $6 \mathrm{~K}$ Vectran webbing loaded to 55\% UTS is noticeably longer the 70 day test period of the two failed $6 \mathrm{~K}$ Vectran webbings loaded to $60 \%$ UTS. In general, data from group 3 indicate two webbing failure definitions of 52\% UTS over a 80 day period for $6 \mathrm{~K}$ Kevlar and 61\% UTS over a 70-day period for 6K Vectran. $48 \%$ UTS Kevlar and 55\% UTS Vectran cases indicate how a small decrease in applied load can extend webbing life.

Group 4 provides short-term data from $12.5 \mathrm{~K}$ Kevlar and $12.5 \mathrm{~K}$ Vectran webbings. Creep displacements for two $12.5 \mathrm{~K}$ Kevlar webbings loaded to $22 \%$ UTS are presented in Figure 29, and creep displacements for two 12.5K Vectran webbings loaded to 23\% UTS are presented in Figure 30. Both graphs exhibit increasing displacements over 150 -day period. One can speculate that the additional yarns required for $12.5 \mathrm{~K}$ webbings versus $6 \mathrm{~K}$ webbings require more time to realign under load and that near constant displacements will be exhibited as time increases.

Comparison of data from a study of the UTS per webbing roll and the four webbing groups, suggest several long term webbing characteristics and practical design considerations. In general the test data indicates a sizeable variance in the UTS of supplied webbing rolls. Variances in webbing rolls and tested webbing samples make general conclusions about the behavior of webbings less accurate. In general, data indicates that a $6 \mathrm{~K}$ Kevlar webbing with an applied load below 40\% UTS would be viable after a one year time period. A 6K Kevlar webbing with an applied load of $45 \%$ UTS or higher would probably not be viable after a one year time period. A $6 \mathrm{~K}$ Vectran webbing with an applied load below $50 \%$ would probably be viable after a one year time period, while a $6 \mathrm{~K}$ Vectran webbing with an applied load of 55\% or higher would probably experience local damage and failure over a one year time period. Limited testing on $12.5 \mathrm{~K}$ Kevlar and $12.5 \mathrm{~K}$ Vectran webbings indicate utilization at loads below $20 \%$ UTS would be feasible for at least seven months. Data also indicates that a $4 \mathrm{~K}$ Kevlar webbing loaded to $32 \%$ UTS would be viable after a one year time period. Comments relative to utilization of particular webbings and applied loads over a two year time period wouldn't be warranted due to insufficient data. Test data are summarized in Table 5 .

Exterior and interior facility ambient temperature data versus time are presented in Figure 31. Graph was generated by selecting temperature data recorded at 12-hour intervals, $4 \mathrm{am}$ and $4 \mathrm{pm}$ per day, from a master data file from a data logger. Exterior temperatures at $4 \mathrm{am}$ and $4 \mathrm{pm}$ per day were obtained from a Langley Air Force Base weather website. The Langley Air Force Base is located approximately 2 miles from LaRC. This data indicates that despite the lack of temperature and humidity control within the facility, the facility provides some inherent temperature regulation. In the winter months, interior temperatures are higher than the more severe exterior temperatures, and in the summer months, interior temperatures are lower than the more extreme exterior temperatures. In general, all recorded interior temperatures fall within the band of outdoor temperatures. The lowest recorded interior temperature was $37^{\circ} \mathrm{F}$, and it occurred on January 24, 2013, and the highest recorded interior temperature was $91^{\circ} \mathrm{F}$, and it occurred on August 28, 2013. As presented in Figure 22, a steady increase in the 
interior temperature of the test facility seems to have had limited to no effect on the creep displacement of a $6 \mathrm{~K}$ Kevlar webbing loaded to $40 \%$ UTS.

Photos of pristine, suspended, and damaged webbings are presented and discussed. A photo of a twenty-one month old 4K Kevlar webbing under 33\% UTS load next to a pristine 4K Kevlar webbing segment is presented in Figure 32a. The suspended webbing has narrowed, and darkened due to oxidation, exposure to light, and facility dust and dirt particles. A photo of a twenty-one month old 6K Vectran webbing under 27\% UTS load next to a pristine $6 \mathrm{~K}$ Vectran webbing segment is presented in Figure $32 \mathrm{~b}$. The suspended webbing appears darker due to facility dust and dirt particles. $6 \mathrm{~K}$ Vectran webbing with local damage is presented in Figure 33. All failed webbings experienced local damage along the length of the webbing before failure. Failed $6 \mathrm{~K}$ Kevlar webbing from group 3 is presented in Figure 34a. Photo indicates a fairly clean break across the width of the webbing. The graph in Figure 25 suggest a quick break by exhibited short tertiary stage. Failed 6K Vectran webbing from group 3 is presented in Figure 34b. Photo indicates a quasi shear break across the diagonal of the webbing. The graph in Figure 27 suggests a prolonged break by exhibited, relative to Kevlar, extended tertiary stage. Five failed webbings and one damaged Kevlar webbing from group 3 are presented in Figure 35. Photo illustrates that webbing failures occurred away from restraint ends.

\section{Conclusion}

The long-term creep behavior of four groups of high strength Kevlar and Vectran webbings was studied under low to medium applied loads. Typical variances in UTS values per roll of webbing were noticed. Webbings were tested in uniquely designed test stands within a large test facility. Displacement-versus-time graphs were generated for all webbings. Strain-versus-time graphs were generated for select group of webbings. Test data indicates that $6 \mathrm{~K}$ Vectran webbings can sustain higher loads than $6 \mathrm{~K}$ Kevlar webbings over extended periods of time. Data indicates that an applied load of 45\% UTS or higher will lead to failure of $6 \mathrm{~K}$ Kevlar webbings over a one year period of time, while a load of 55\% UTS or higher will lead to failure of $6 \mathrm{~K}$ Kevlar webbings over a one year period of time. $6 \mathrm{~K}$ Vectran webbings seem to have a smaller primary stage and a longer tertiary stage than $6 \mathrm{~K}$ Kevlar webbings. $4 \mathrm{~K}$ Kevlar webbings exhibited long-term, (twenty-one months), life loaded to 33\% UTS, and 12.5K Kevlar and Vectran webbings exhibited classic creep behaviors over a relatively short eight-month test period. Visible local damage of a webbing typically preceeds failure, and variations in ambient temperatures within the test facility seems to have had little effect on displacement data of webbings with low applied loads.

\section{Acknowledgments}

Authors would like to thank, "Lightweight Materials \& Structures (LMS)" Project Manager, Lynn Bowman, "Structural Mechanics \& Concepts” Branch Head, David Brewer, and LMS, Senior Technical Advisor, Judith Watson, for valuable and constructive suggestions during setup and implimentation of this experimental study. Authors would also like to thank Joseph G. Sikora, Dr. Mark J. Shuart, Sherry Monk, Sandra Walker, James Phelps, Martin J. McKenney, Thomas W. Jones, Harriett Dismond, and Mary Jane E. O'Rourke. Assistance provided by personnel in the Materials Experiment Branch, Structures Experiments Branch, Aerospace Composite Model Development Section, and Structures Testing Branch was appreciated. Finally, I would like to thank my parents for their love and support.

\section{References}

\footnotetext{
${ }^{1}$ DelaFuente Horacio, Raboin, Jasen L, Spexarth, Gary R., and Valle, Gerard D., (2000) TransHab: NASA's Large-Scale Inflatable Spacecraft. AIAA-2000-1822, AIAA Space Inflatables Forum, Atlanta (Georgia), April 3-6.

${ }^{2}$ Jones, Thomas C., Doggett, William R., Stanfield, Clarence E., "Accelerated Creep Testing of High Strength Aramid Webbing,” AIAA Paper 2012-1771, NF1676L-13173, 53rd AIAA/ASME/ASCE/AHS/ASC Structures, Structural Dynamics and Materials Conference; 23-26 Apr. 2012; Honolulu, HI; United States.

${ }^{3}$ Lichodziejewski, D., Kelley, C., Tutt, B., Brown, G., "Design and Testing of the Inflatable Aeroshell for the IRVE-3 Flight Experiment," AIAA Paper 2012-1771, NF1676L-13173, 53rd AIAA/ASME/ASCE/AHS/ASC Structures, Structural Dynamics and Materials Conference; 23-26 Apr. 2012; Honolulu, HI; United States.
} 
${ }^{4}$ Cavallaro, Paul V., Johnson, Matthew E., Sadegh, Ali M., "Mechanics of Plain-Woven Fabrics for Inflatable Structures," Symposium on Design and Manufacturing of Composites, Composite Structures, Volume 61, Issue 4, September 2003, Pages 375-393.

${ }^{5}$ Lin, John K. H., Sapna III, George H., Cadogan, David P., Scarborough, Stephen E., "Inflatable Rigidizable Isogrid Boom Development,", AIAA 2002-1297, 43 ${ }^{\text {rd }}$ AIAA/ASME/ASCE/AHS/ASC Structures, Structural Dynamics, and Materials Conference \& Exhibit AIAA Gossamer Spacecraft Forum, April 22-25, 2002, Denver, CO.

${ }^{6}$ Findley, William N., Lai, James S., Onaran, Kasif, Creep and Relaxation of Nonlinear Viscoelastic Materials. Copyright 1976, North-Holland Publishing Company.

7Jones, Thomas C., Doggett, William R., "Time-Dependent Behavior of High-Strength Kevlar and Vectran Webbings", 55th AIAA/ASME/ASCE/AHS/ASC Structures, Structural Dynamics, and Materials Conference, January 13-17, 2014, National Harbor, Maryland (submitted for publication).

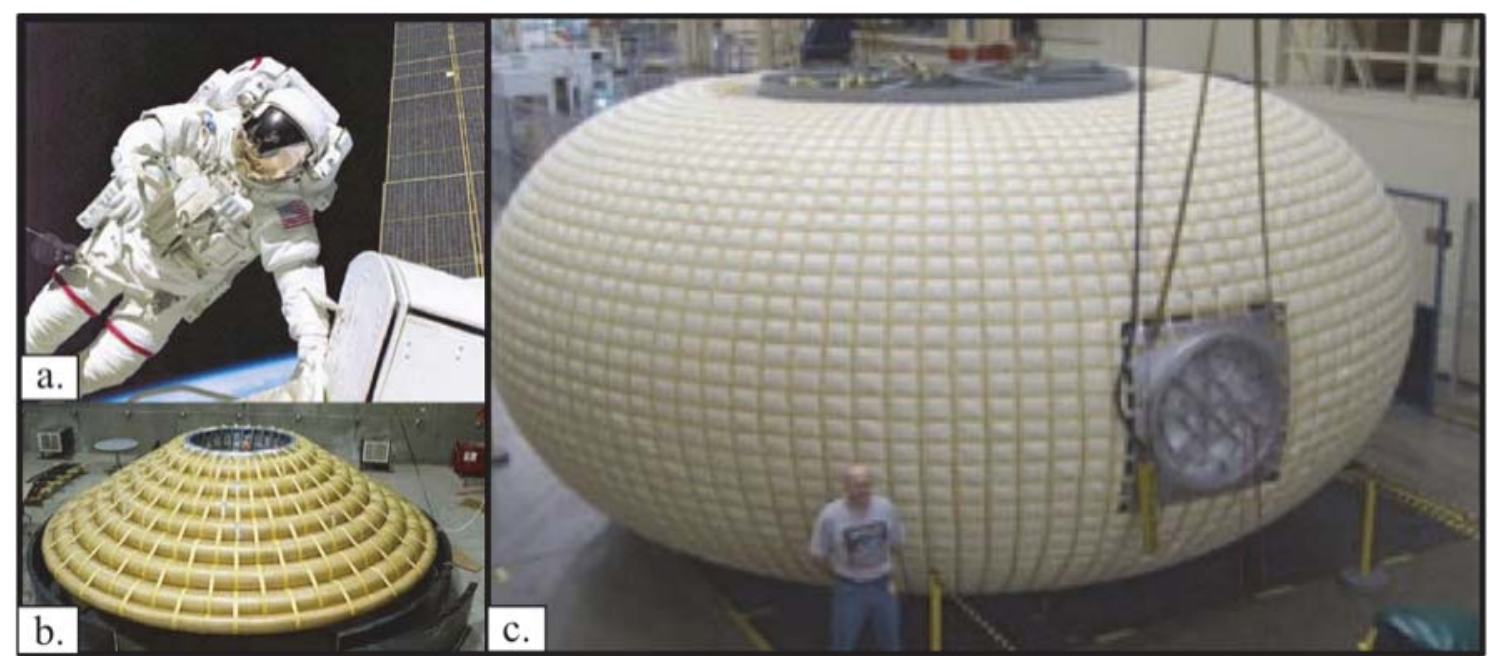

Figure 1. Examples of inflatable structures, a.) astronaut extra-vehicular activity (EVA) suit, b.) Inflatable aeroshell, and c.) Inflatable habitat with torus geometry.

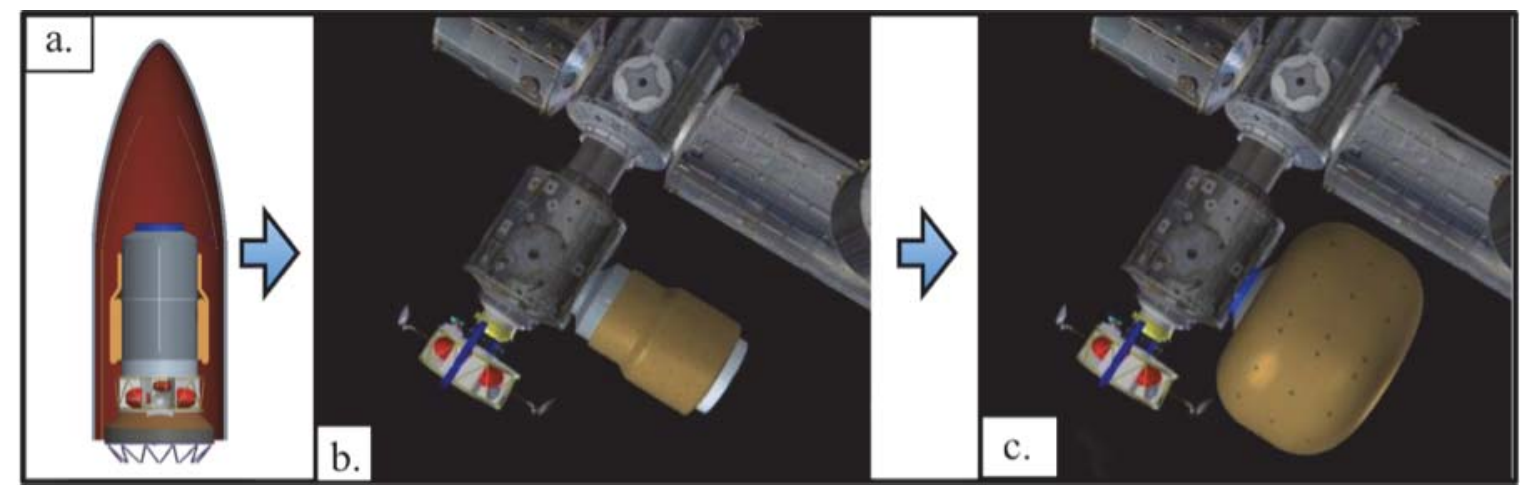

Figure 2. Conceptual vision of inflatable structure from payload to operational module, a.) payload, b.) attached to space station, and c.) deployed and operational. 

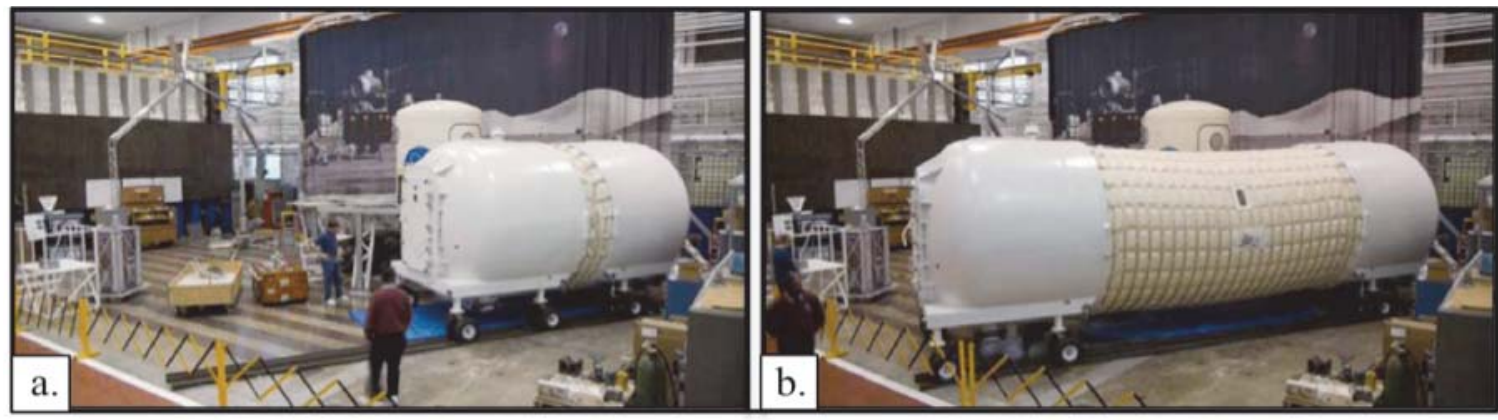

Figure 3. Demonstration of deployment of an expandable technology demonstrator module designed for Lunar or Mars surface applications.

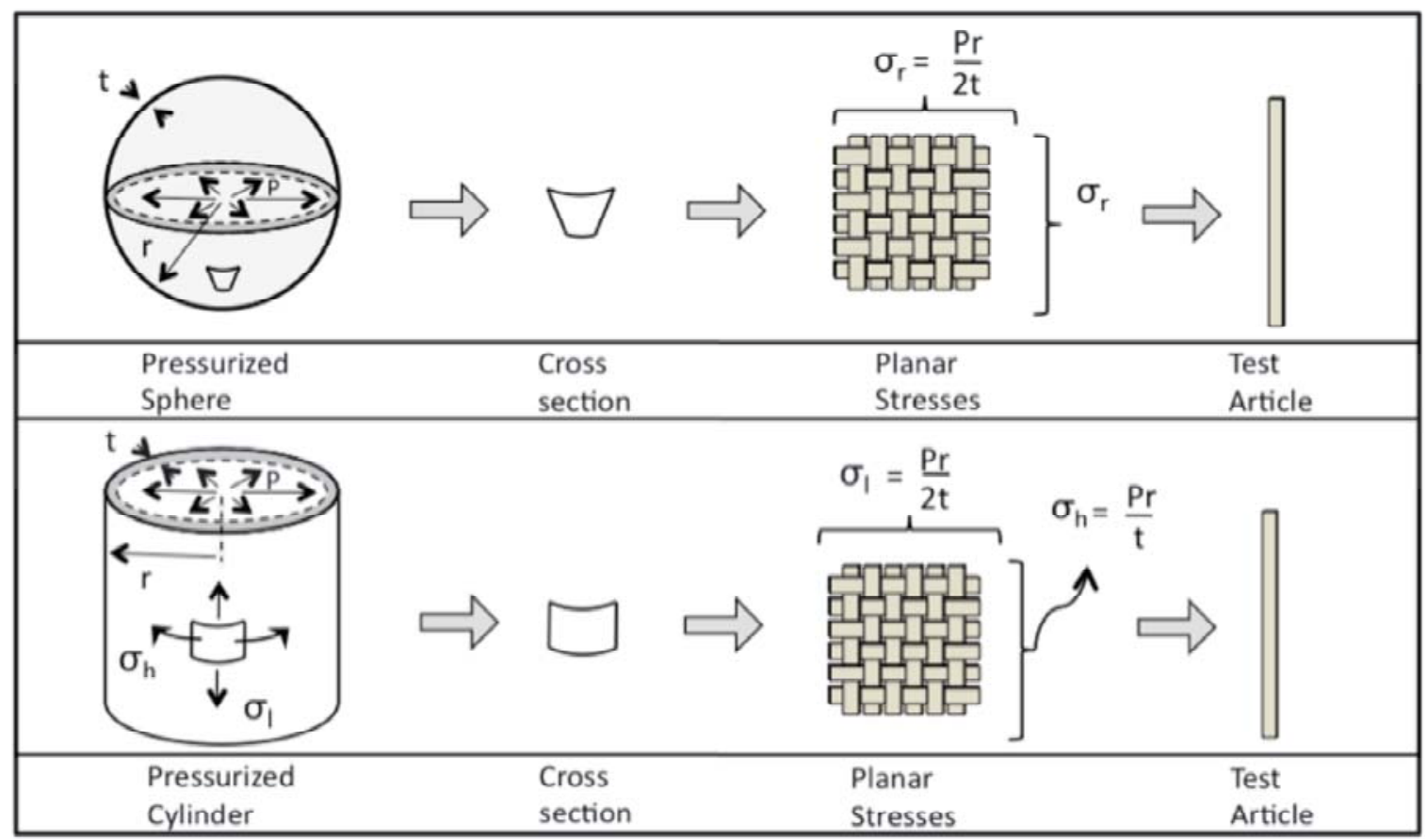

Figure 4. Basic pressure vessel equations and load effect on webbing. 


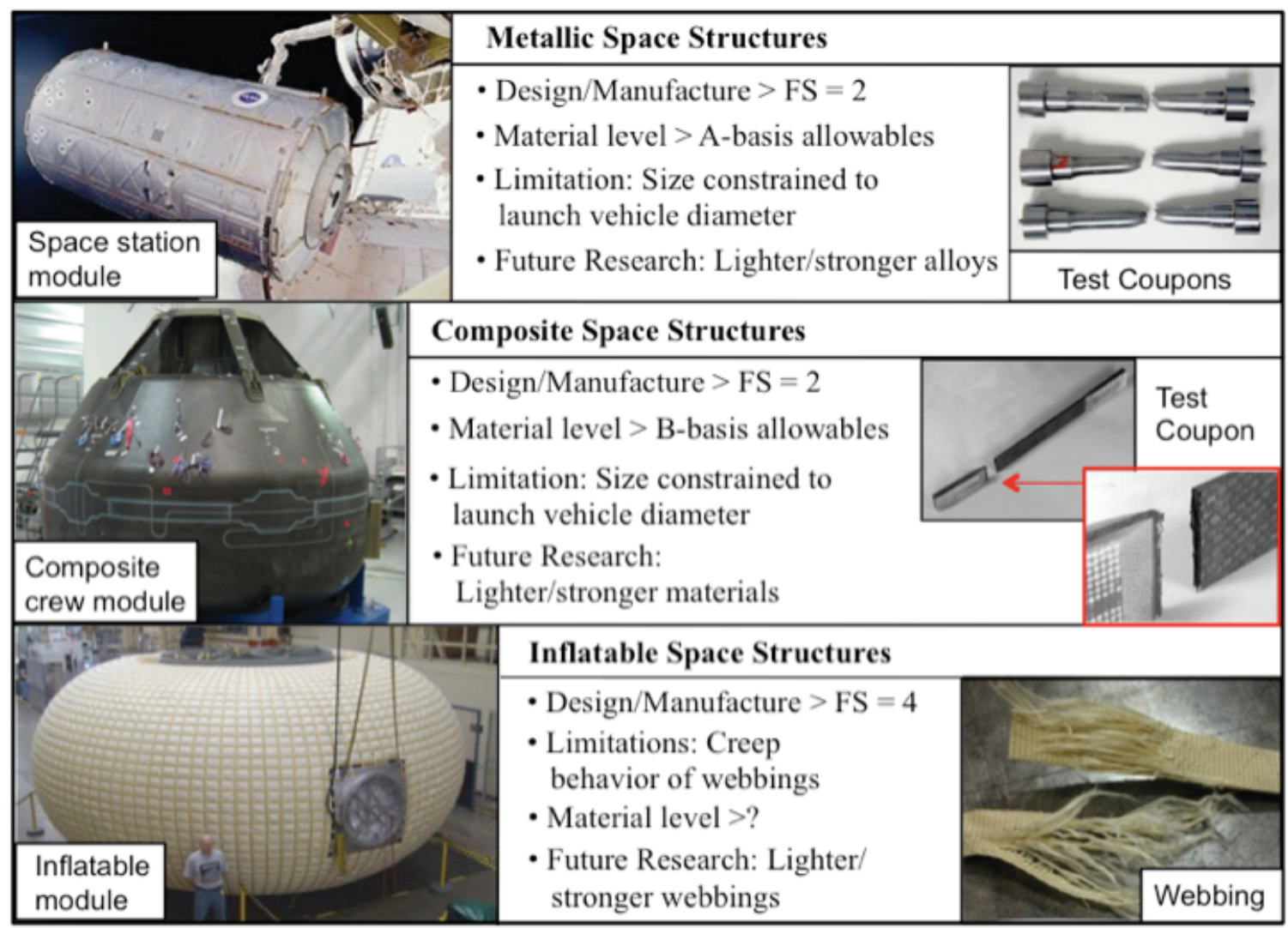

Figure 5. Aerospace materials database review.

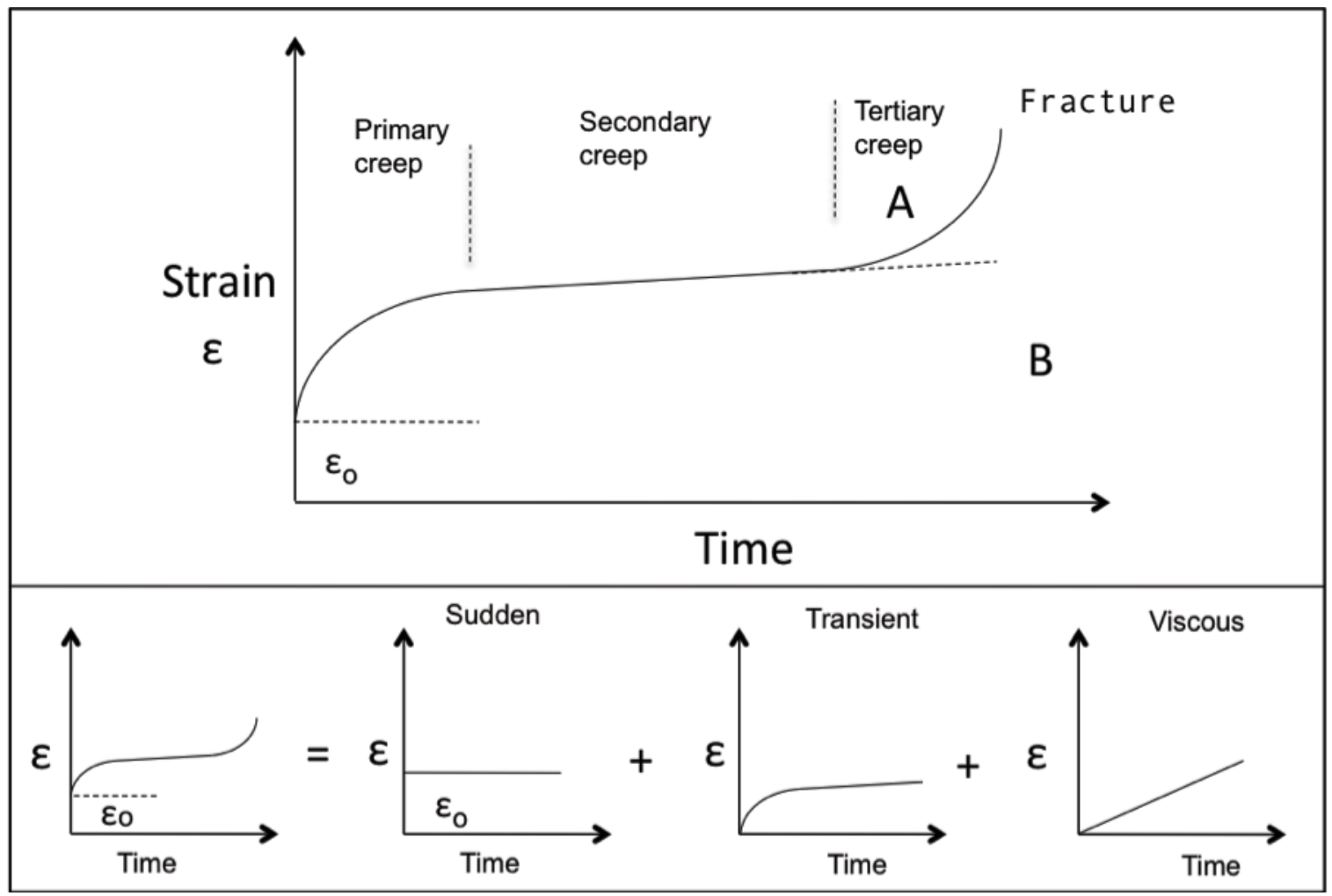

Figure 6. Three stages of a creep curve. 


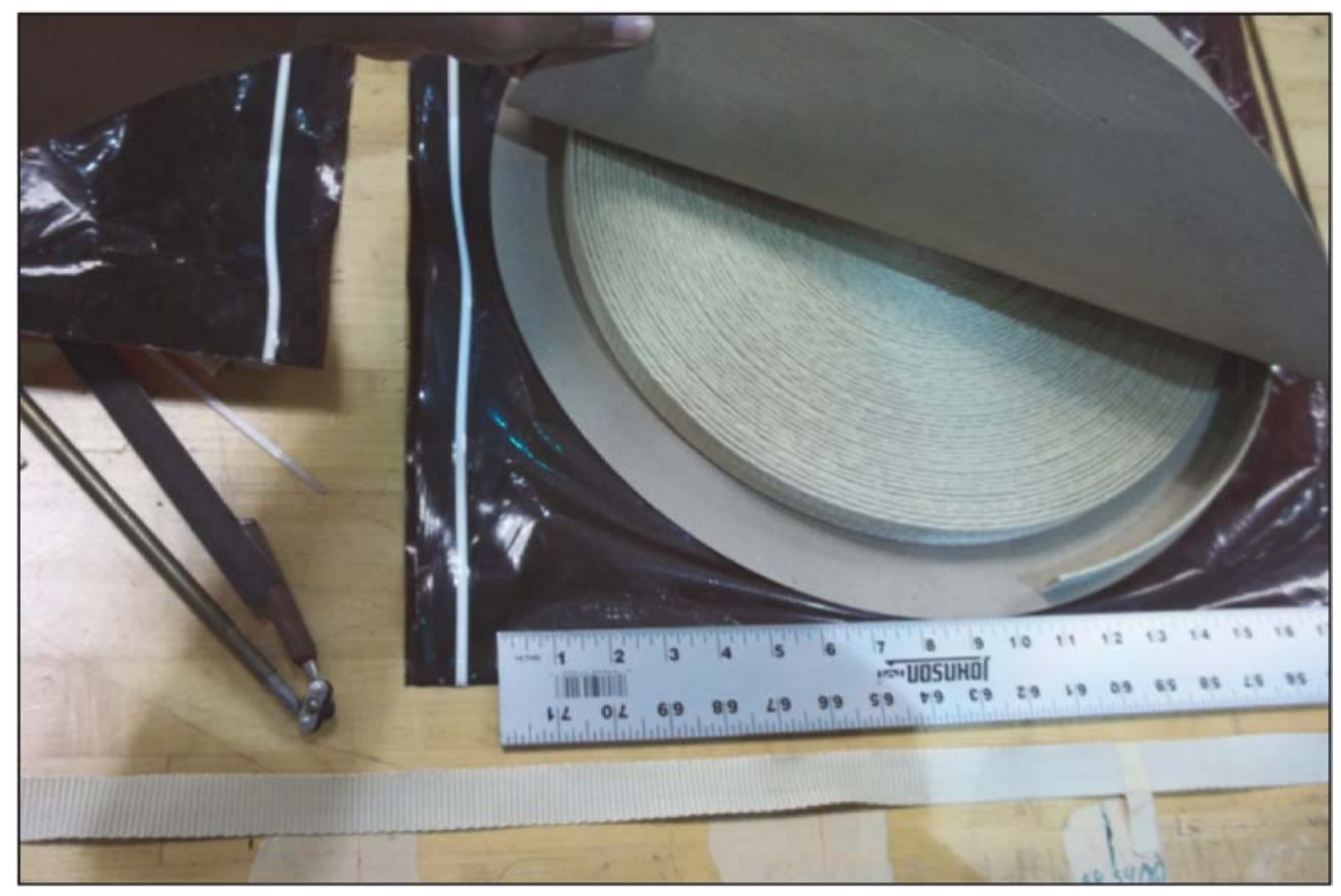

Figure 7. Typical roll and segment of Vectran webbing. 


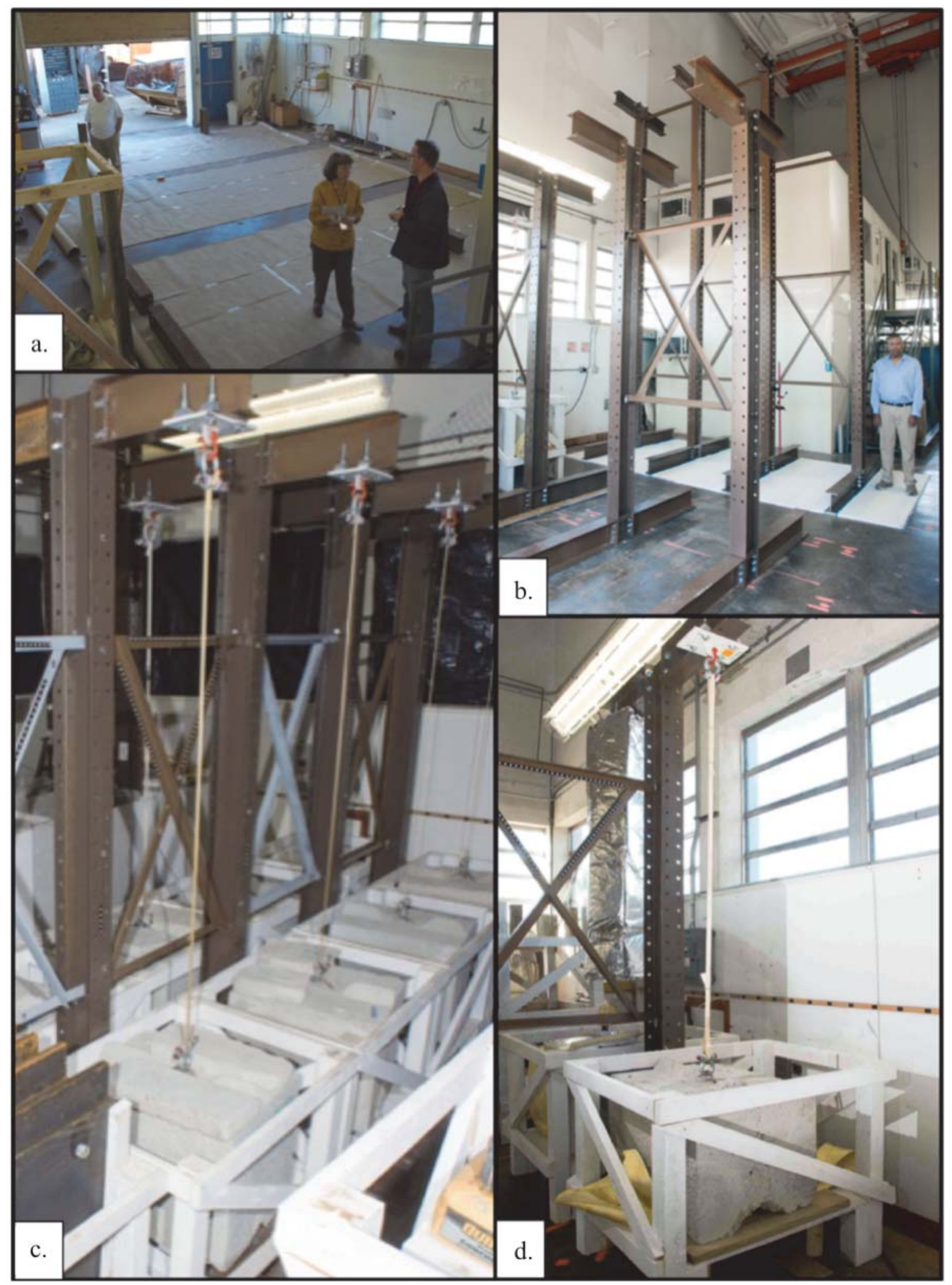

Figure 8. Test facility build: a.) empty facility, b.) two rows of double cantilevered I-beam structure, c.) row one of Kevlar \& Vectran creep tests, d.) typical creep test. 


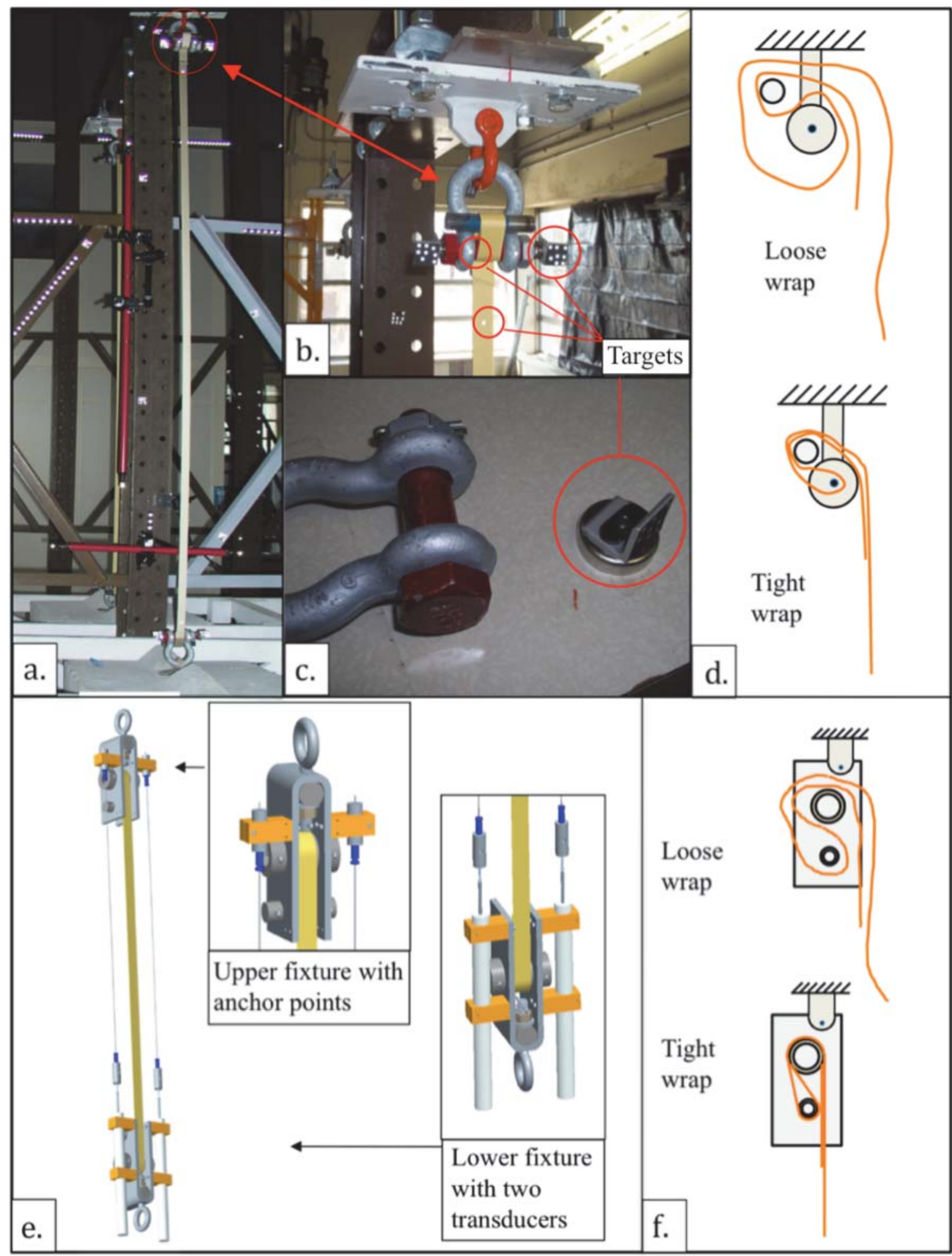

Figure 9. Basic and custum restraint hardware; a.) typical creep test stand, b.) basic restraint hardware consisting of shackle and pin, and photogrammetry targets, c.) typical shackle, d.) basic webbing restraining wrap, e.) image of custom restraint hardware with two transducer sensors, f.) custom webbing restraining wrap. 


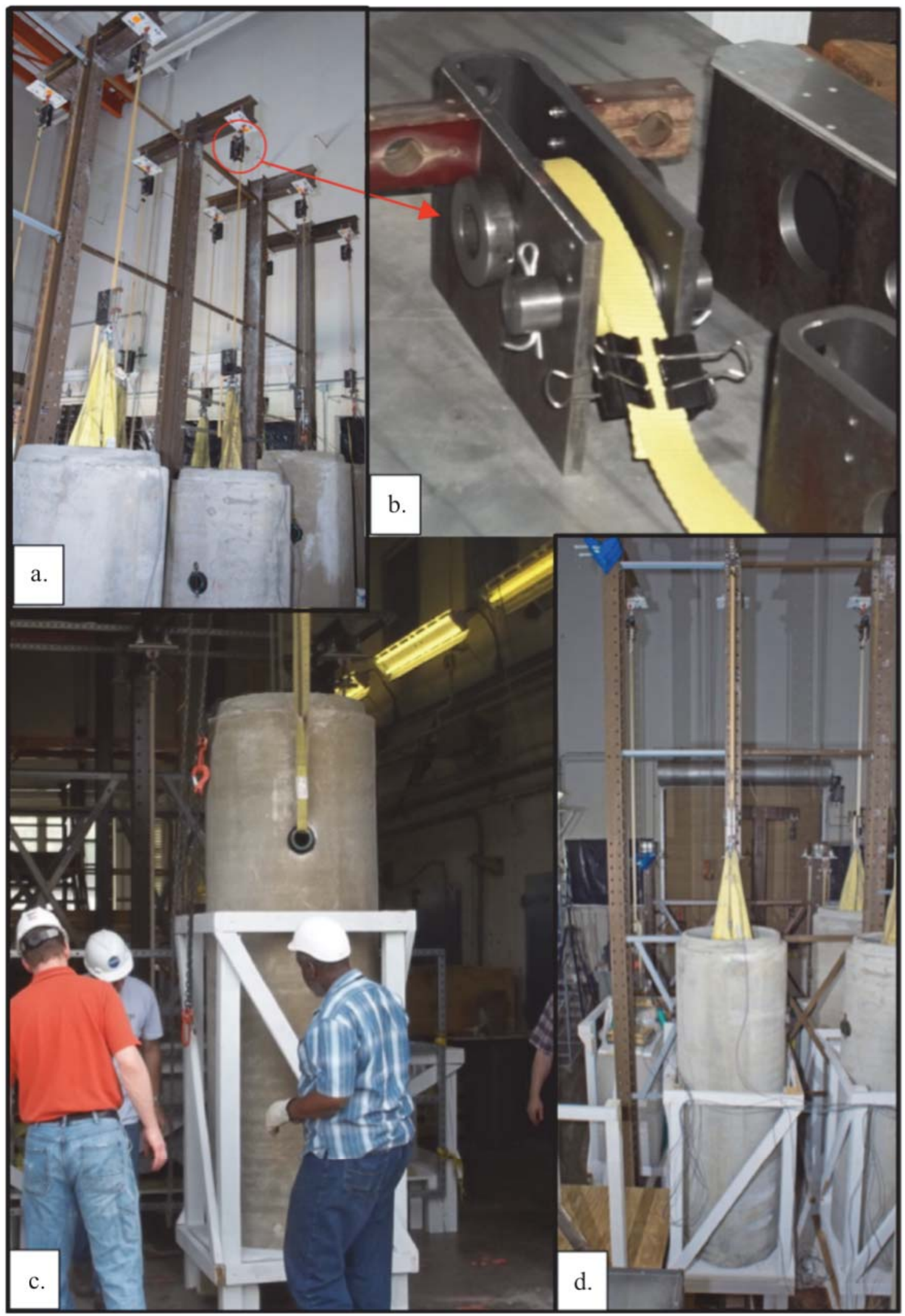

Figure 10. Hardware for second row of creep tests; a.) four Kevlar tests, b.) custom restraint fixture with webbing, c.) concrete culvert weight, d.) typical creep test. 


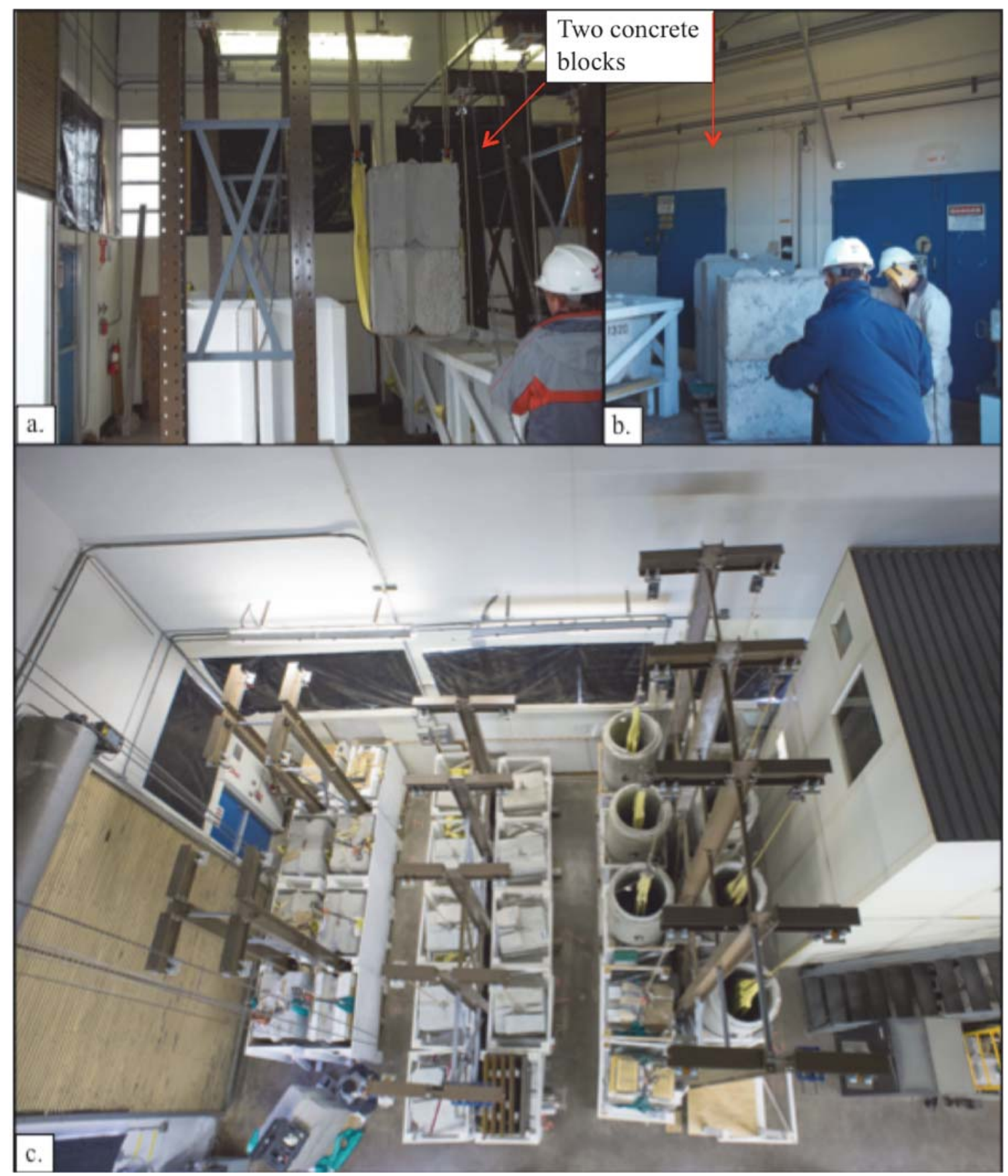

Figure 11. Hardware for third row of creep tests and top view of test site; a.) two concrete block weights being lifted into containment structure, b.) positoning of two concrete blocks with pallet jack, c.) top view of fully populated and operational creep test facility. 


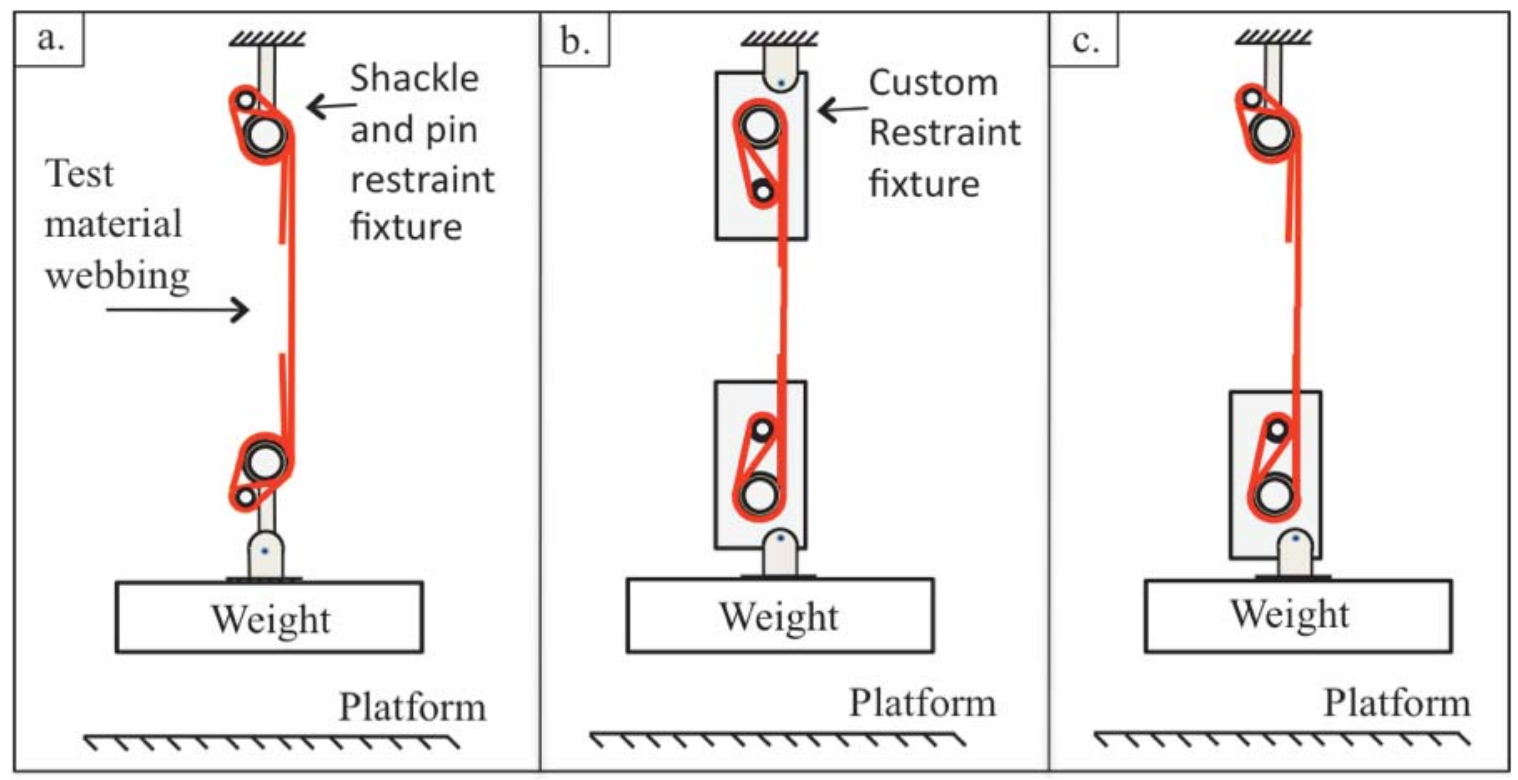

Figure 12. Basic and custom webbing restraint fixture definitions.

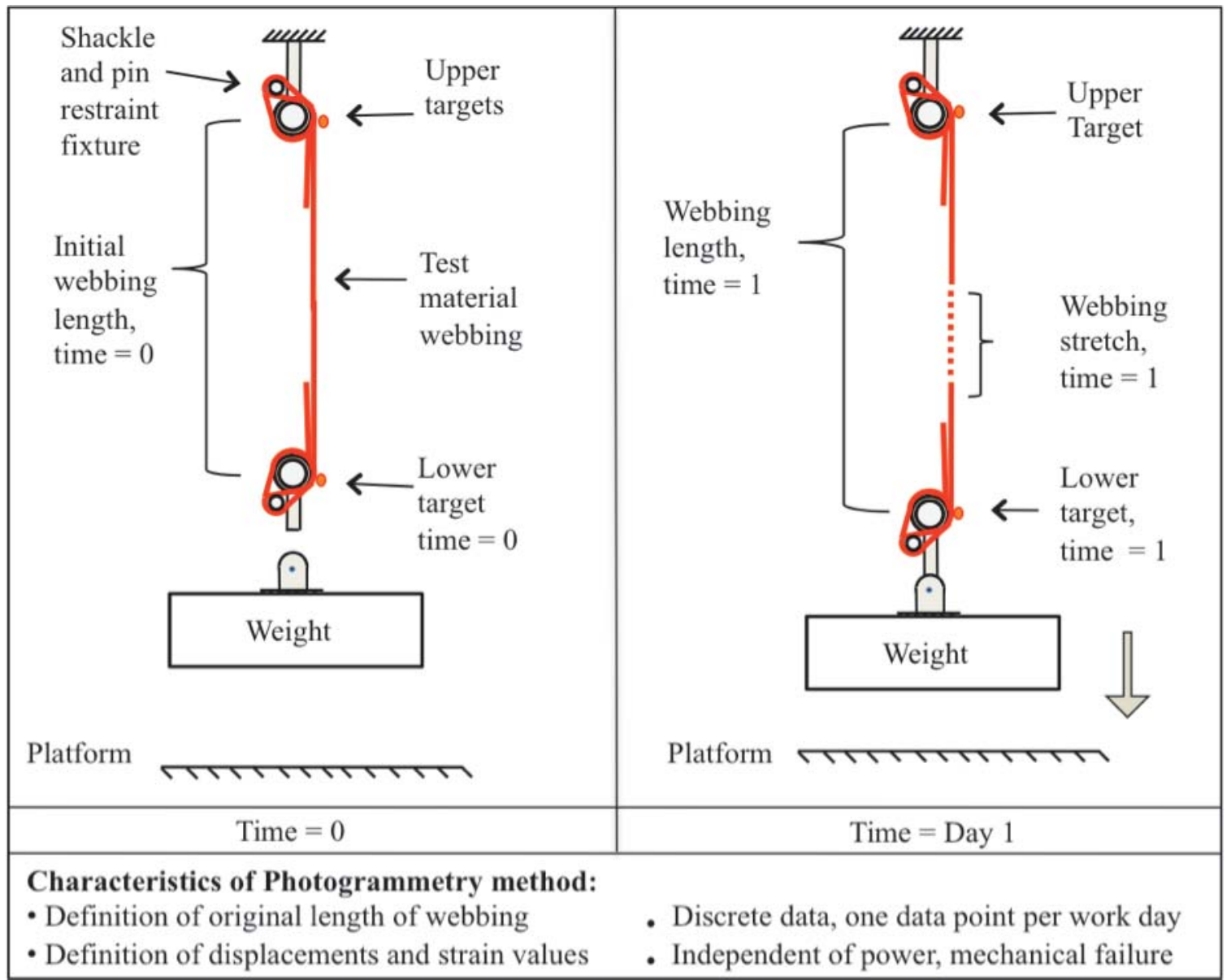

Figure 13. Overview of hardware and how photogrammetry method is utilized to acquire webbing displacements over time. 


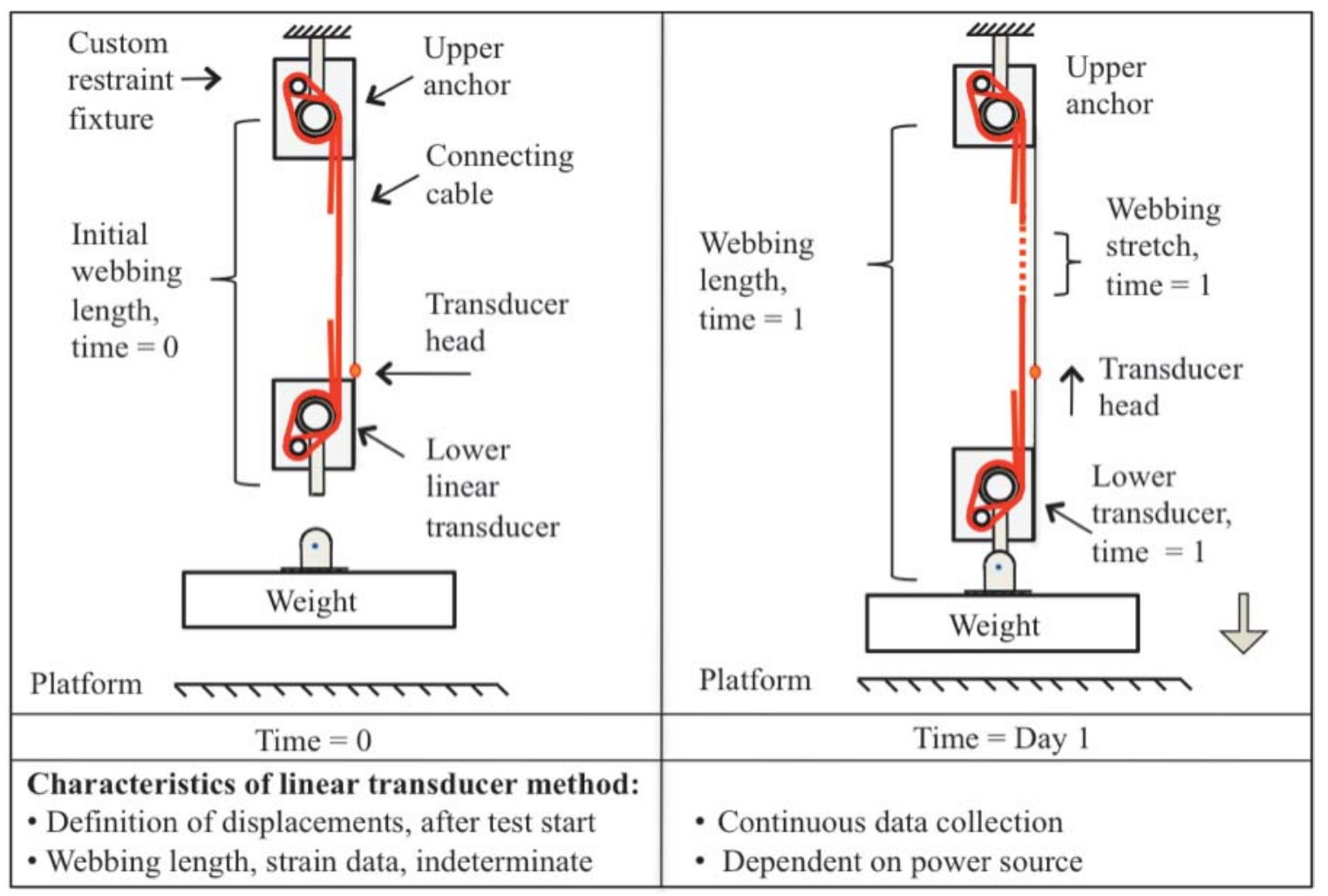

Figure 14. Overview of hardware and how linear transducer method is utilized to acquire webbing displacements over time.

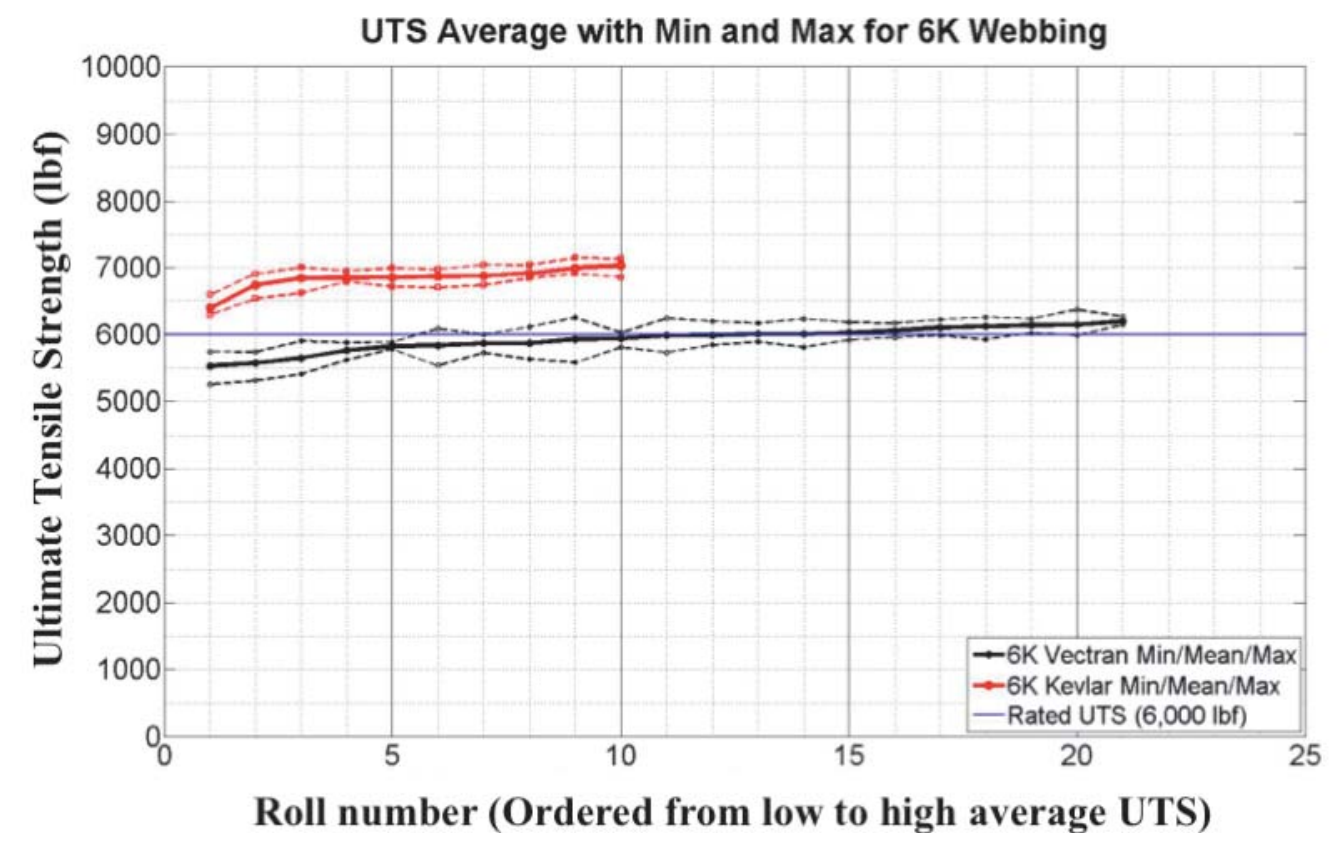

Figure 15. 6K Kevlar and Vectran minimum, mean and maximum ultimate tensile strengths for every roll of material tested. Solid line is the mean, dashed lines are minimum / maximum values per roll. 


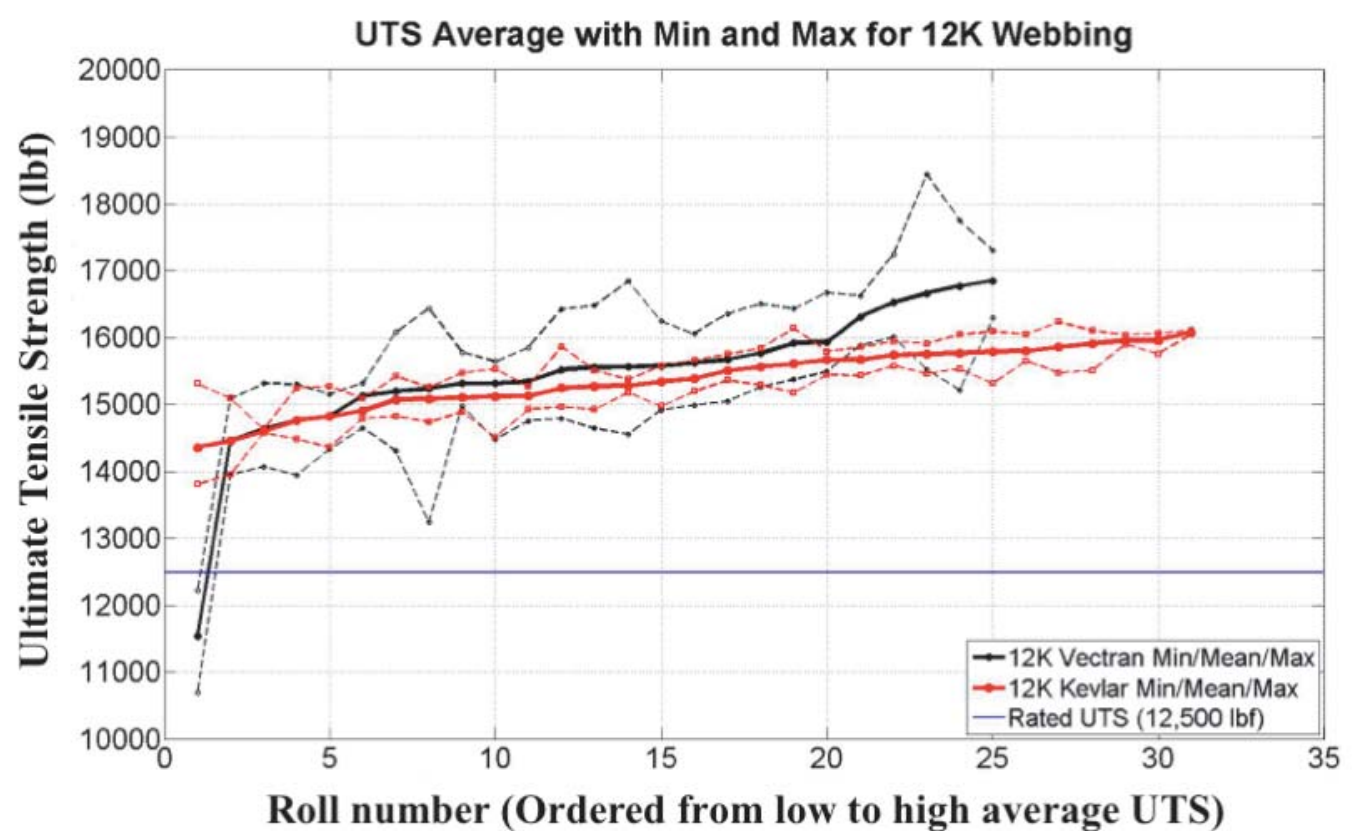

Figure 16. 12.5K Kevlar and Vectran minimum, mean and maximum ultimate tensile strengths for every roll of material tested. Solid line is the mean, dashed lines are minimum / maximum values per roll.

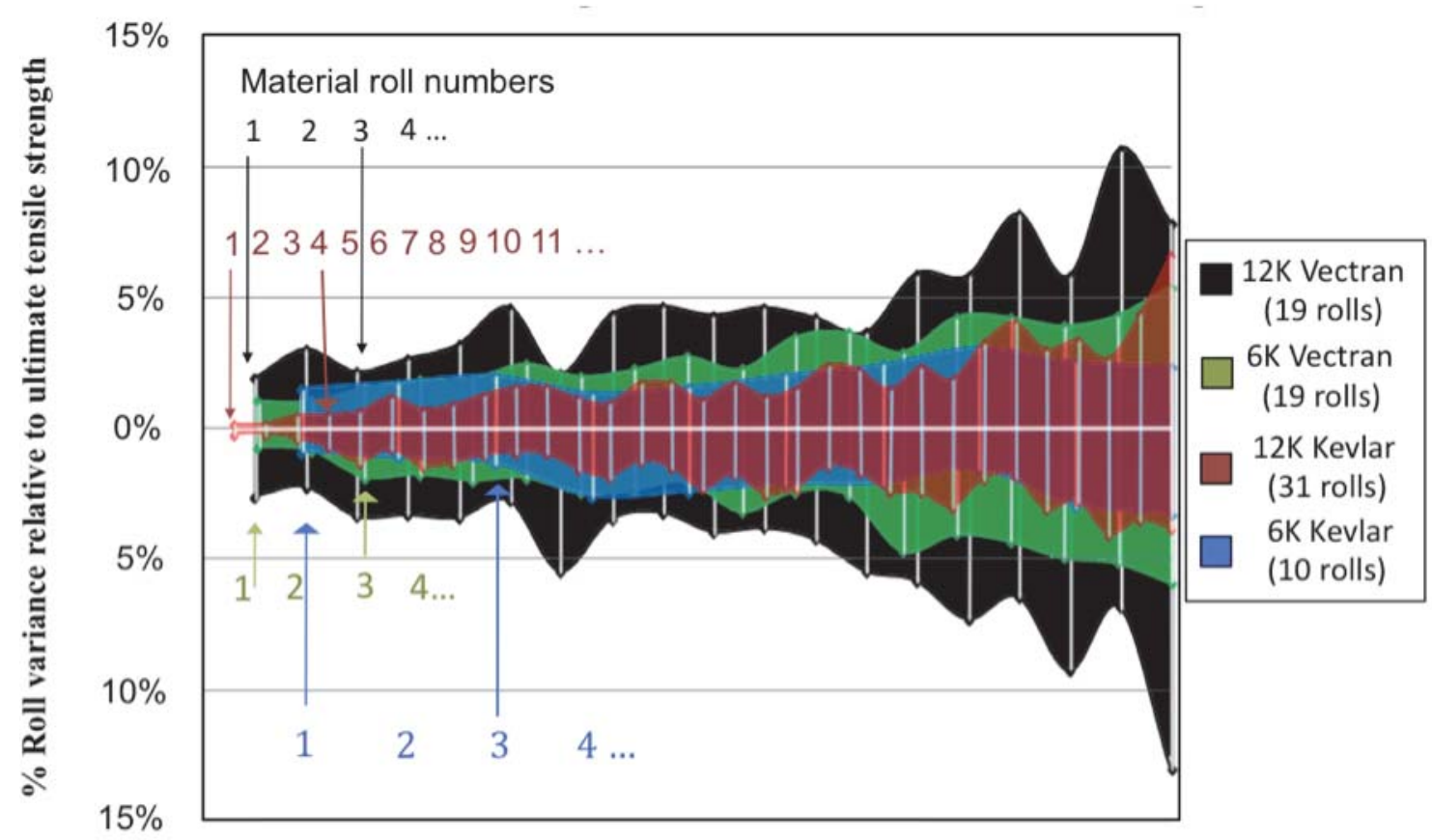

Rolls ordered by increasing variance

Figure 17. 6K Kevlar, 6K Vectran, 12.5K Kevlar, 12.5K Vectran \% variance about mean UTS for all rolls tested. Plot is normalized by roll number. 


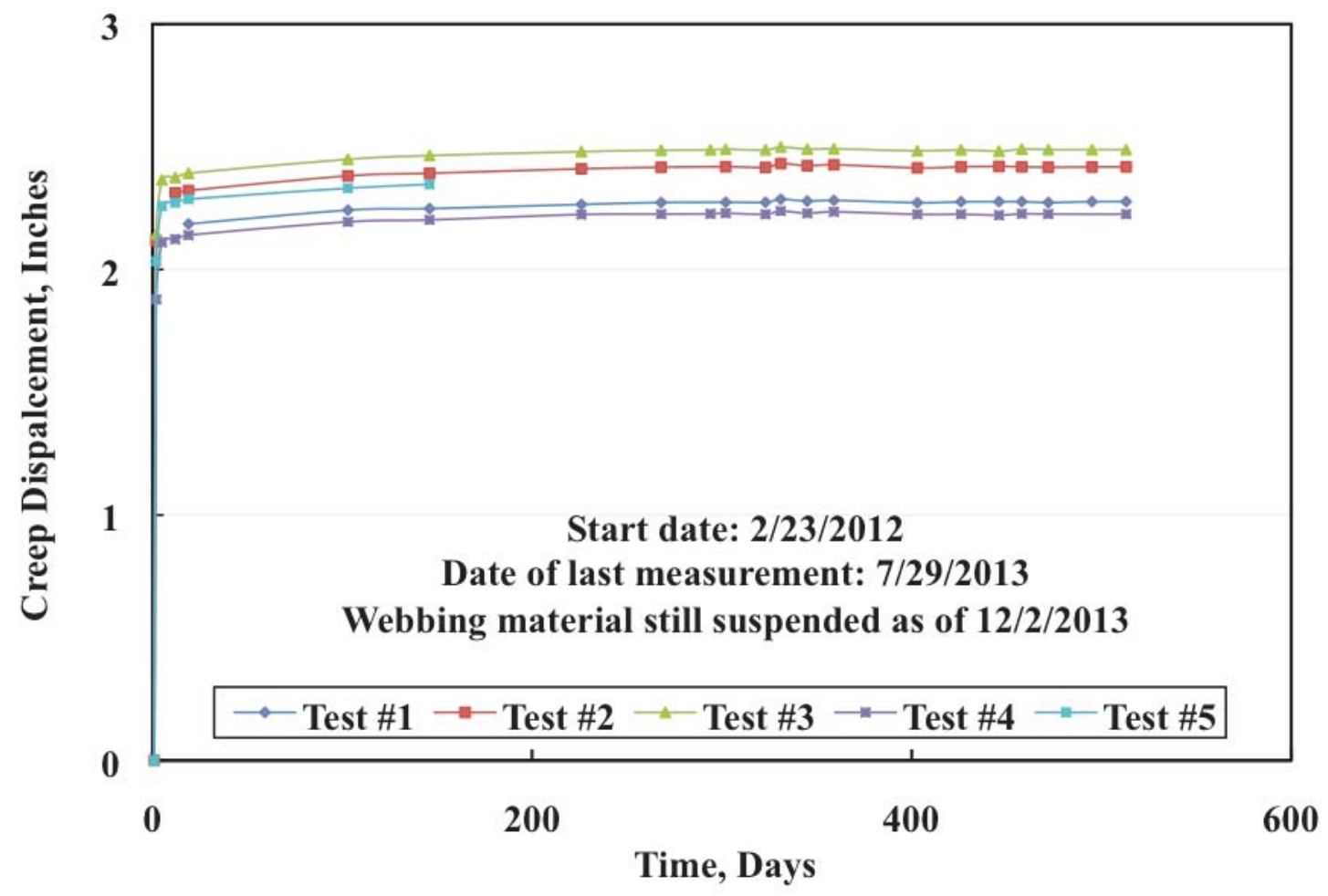

Figure 18. Creep displacements for five 4K Kevlar webbings loaded to $32 \%$ UTS.

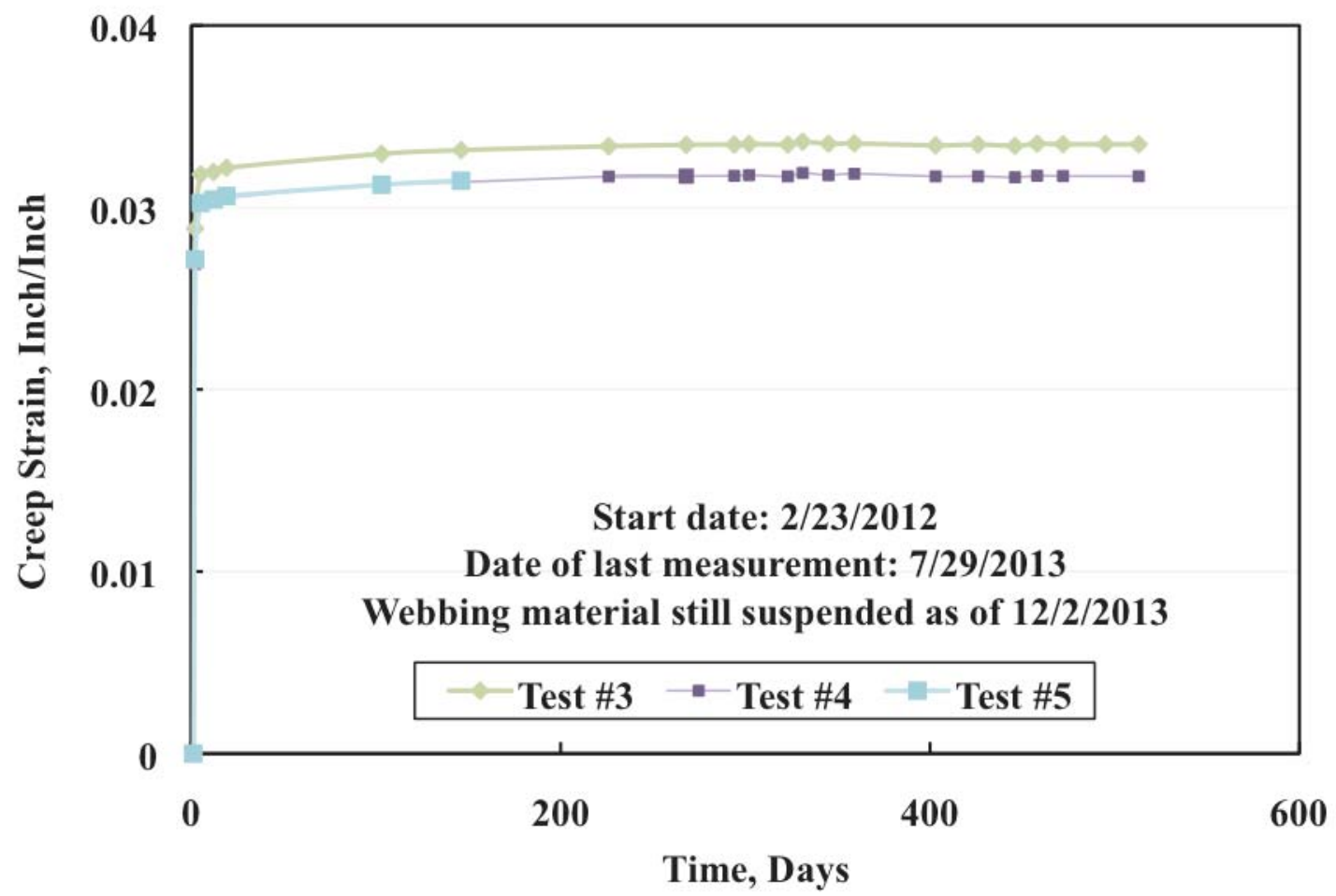

Figure 19. Creep strains for three $4 \mathrm{~K}$ webbings loaded to $32 \%$ UTS. 


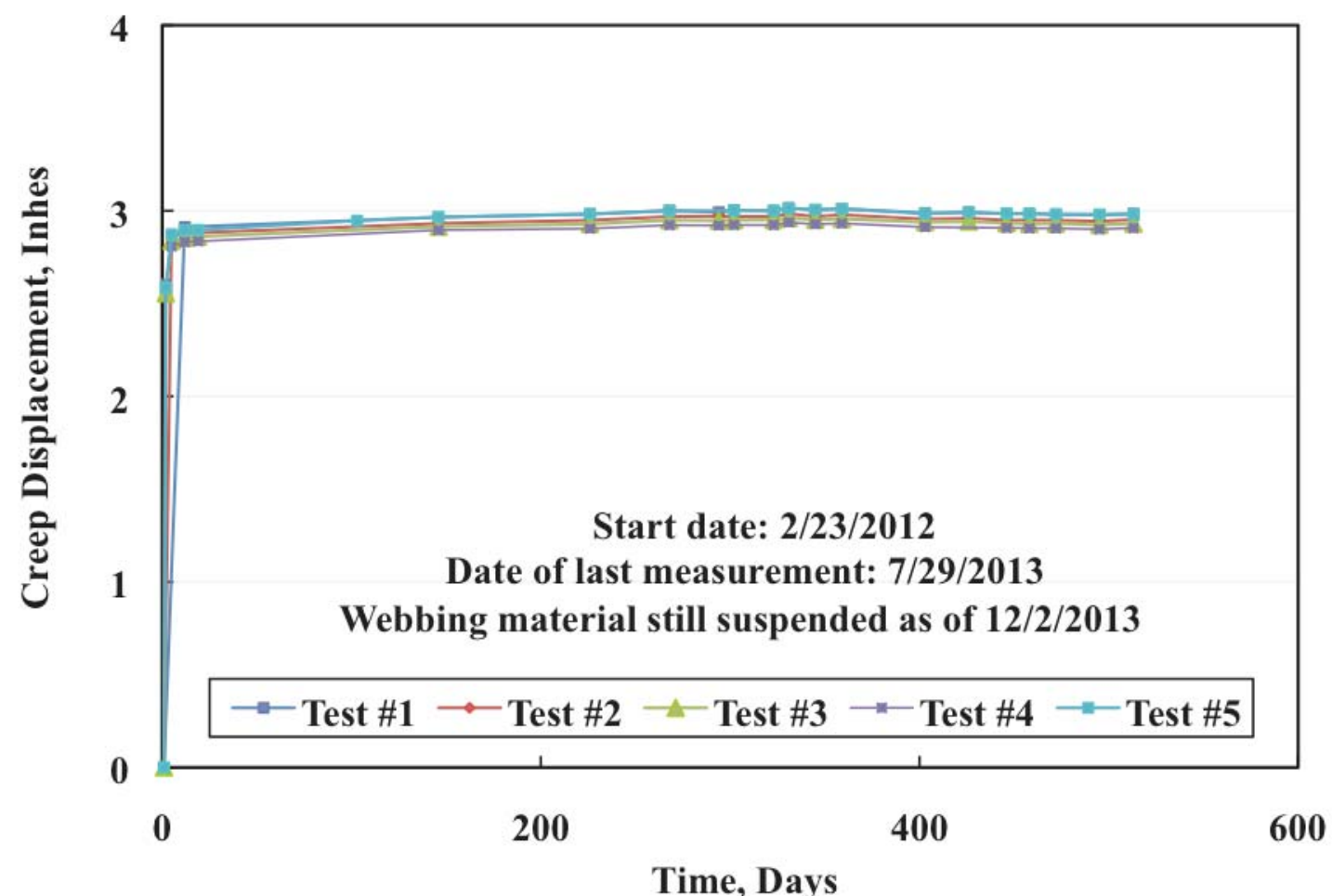

Figure 20. Creep displacements for five 6K Vectran webbings loaded to $26 \%$ UTS.

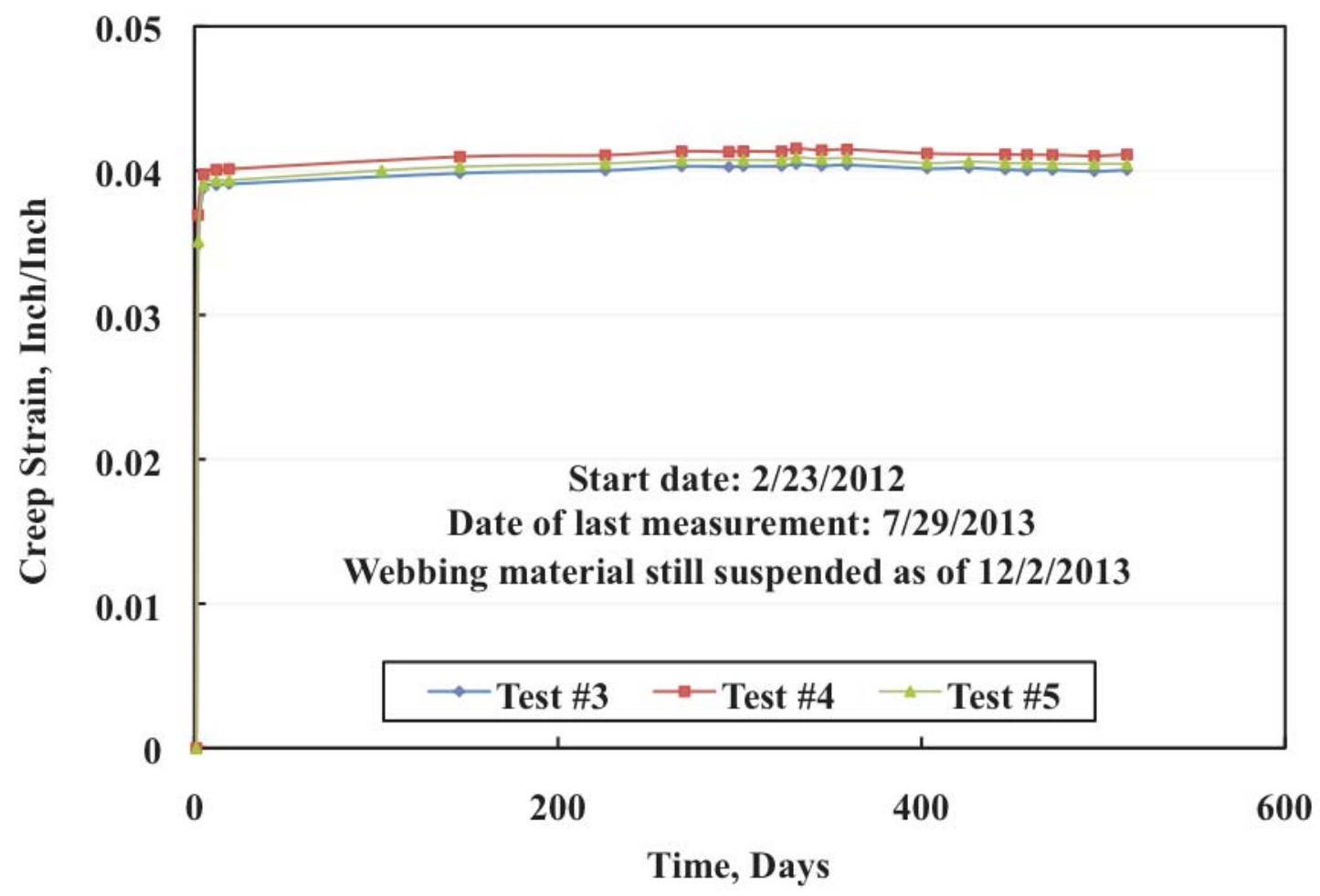

Figure 21. Creep strains for five $6 \mathrm{~K}$ Vectran webbings loaded to $26 \%$ UTS. 


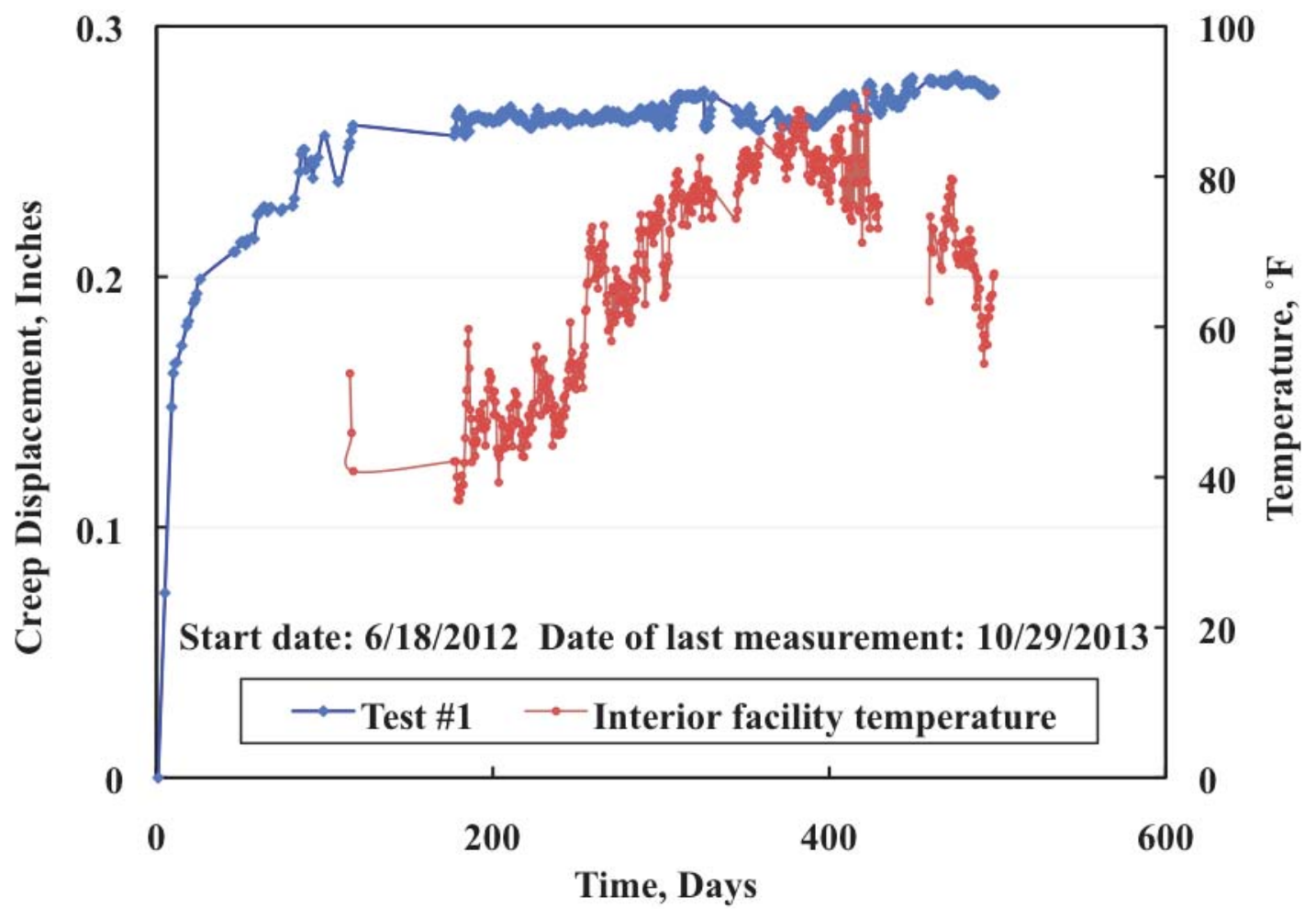

Figure 22. Creep displacement for one $6 \mathrm{~K}$ Kevlar webbing loaded to $40 \%$ UTS, and internal facility temperatures over time period.

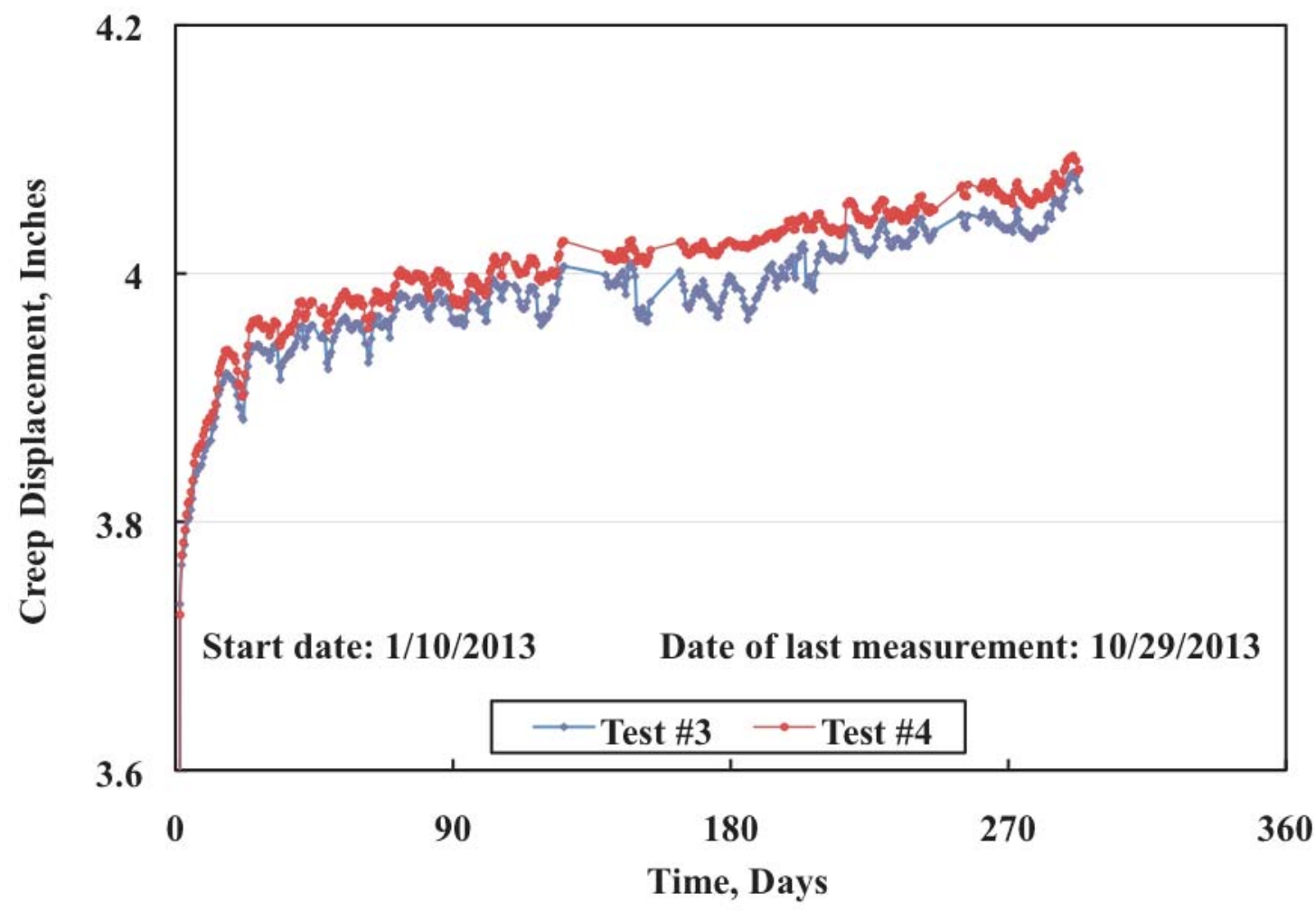

Figure 23. Creep displacements for two $6 \mathrm{~K}$ Kevlar webbings loaded to $43 \%$ UTS. 


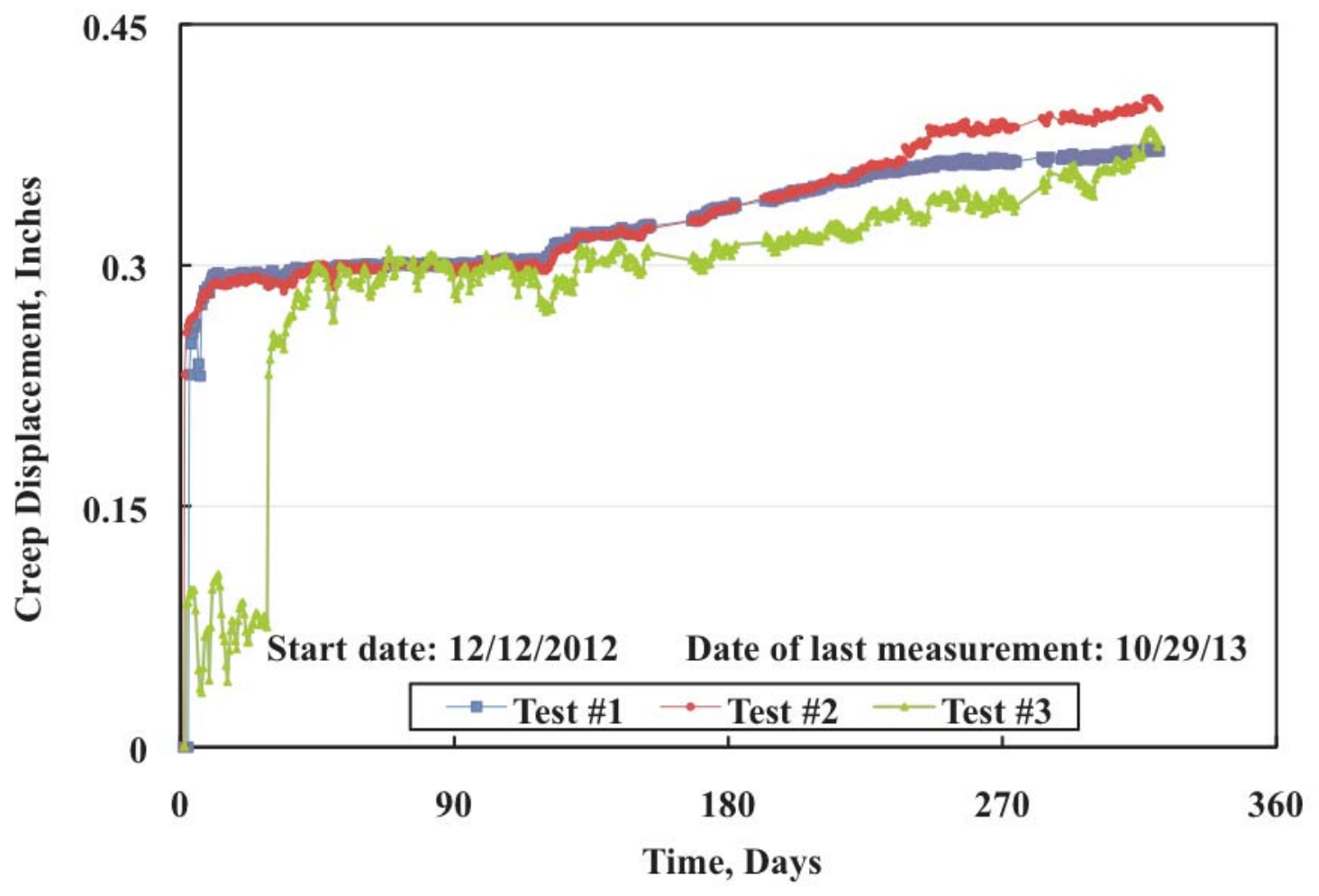

Figure 24. Creep displacements for three 6K Vectran webbings loaded to 49\% UTS.

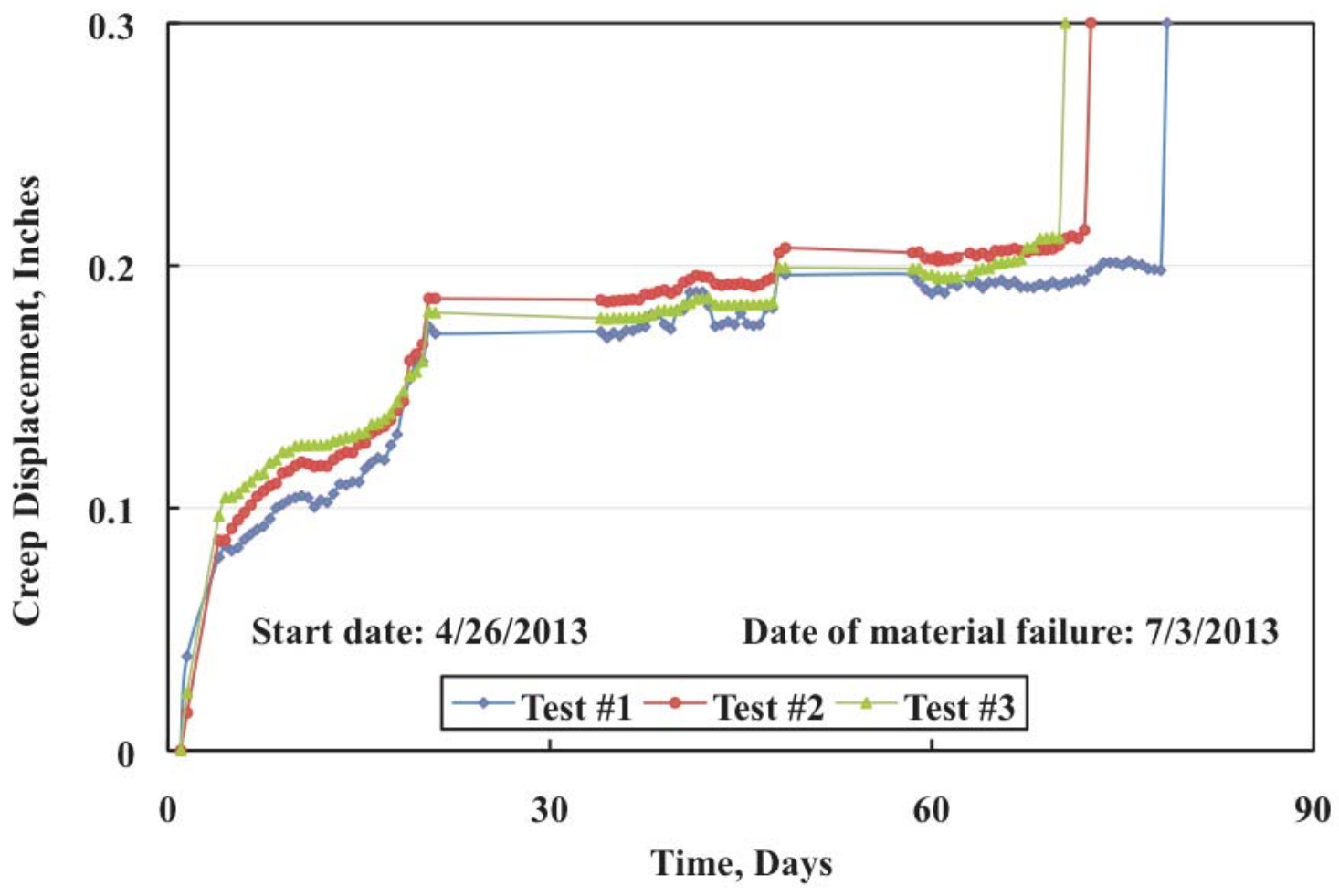

Figure 25. Creep displacements for three 6K Kevlar webbings loaded 52\% UTS. 





